\title{
Involvement of HTLV-I Tax and CREB in aneuploidy: a bioinformatics approach
}

\author{
Cynthia de la Fuente ${ }^{1}$, Madhur V Gupta ${ }^{1}$, Zachary Klase ${ }^{1}$, Katharine Strouss ${ }^{1}$, \\ Patrick Cahan ${ }^{1}$, Timothy McCaffery ${ }^{1}$, Anthony Galante ${ }^{2}$, \\ Patricia Soteropoulos ${ }^{2}$, Anne Pumfery ${ }^{1}$, Masahiro Fujii ${ }^{4,5}$ and \\ Fatah Kashanchi*1,3
}

\begin{abstract}
Address: ${ }^{1}$ The George Washington University Medical Center, Department of Biochemistry and Molecular Biology, Washington, DC 20037, USA, ${ }^{2}$ Center for Applied Genomics, Public Health Research Institute, Newark, NJ 07103, USA, ${ }^{3}$ The Institute for Genomic Research (TIGR), Rockville, MD 20850, USA, ${ }^{4}$ Department of Immunotherapeutics, Niigata University School of Medicine, Asahimachi-Dori, Niigata 951-8510, Japan and ${ }^{5}$ Department of Virology, Niigata University School of Medicine, Asahimachi-Dori, Niigata 951-8510, Japan

Email: Cynthia de la Fuente - bcmclf@gwumc.edu; MadhurV Gupta - bcmmvg@gwumc.edu; Zachary Klase - zklase@gwu.edu; Katharine Strouss - strouss@gwu.edu; Patrick Cahan - Patrick.cahan@gmail.com; Timothy McCaffery - mcc@gwu.edu; Anthony Galante - galante@phri.org; Patricia Soteropoulos - patricia@phri.org; Anne Pumfery - pumferan@shu.edu; Masahiro Fujii - fujiimas@med.niigata-u.ac.jp; Fatah Kashanchi* - bcmfxk@gwumc.edu

* Corresponding author
\end{abstract}

Published: 05 July 2006

Retrovirology 2006, 3:43 doi:10.1186/1742-4690-3-43

This article is available from: http://www.retrovirology.com/content/3///43

(c) 2006 de la Fuente et al; licensee BioMed Central Ltd.

This is an Open Access article distributed under the terms of the Creative Commons Attribution License (http://creativecommons.org/licenses/by/2.0), which permits unrestricted use, distribution, and reproduction in any medium, provided the original work is properly cited.

\begin{abstract}
Background: Adult T-cell leukemia (ATL) is a complex and multifaceted disease associated with human T-cell leukemia virus type I (HTLV-I) infection. Tax, the viral oncoprotein, is considered a major contributor to cell cycle deregulation in HTLV-I transformed cells by either directly disrupting cellular factors (protein-protein interactions) or altering their transcription profile. Tax transactivates these cellular promoters by interacting with transcription factors such as CREB/ATF, $\mathrm{NF}-\mathrm{KB}$, and SRF. Therefore by examining which factors upregulate a particular set of promoters we may begin to understand how Tax orchestrates leukemia development.
\end{abstract}

Results: We observed that CTLL cells stably expressing wild-type Tax (CTLL/WT) exhibited aneuploidy as compared to a Tax clone deficient for CREB transactivation (CTLL/703). To better understand the contribution of Tax transactivation through the CREB/ATF pathway to the aneuploid phenotype, we performed microarray analysis comparing CTLL/WT to CTLL/703 cells. Promoter analysis of altered genes revealed that a subset of these genes contain CREB/ATF consensus sequences. While these genes had diverse functions, smaller subsets of genes were found to be involved in $\mathrm{G} 2 / \mathrm{M}$ phase regulation, in particular kinetochore assembly. Furthermore, we confirmed the presence of CREB, Tax and RNA Polymerase II at the p97Vcp and Sgt I promoters in vivo through chromatin immunoprecipitation in CTLL/WT cells.

Conclusion: These results indicate that the development of aneuploidy in Tax-expressing cells may occur in response to an alteration in the transcription profile, in addition to direct protein interactions. 


\section{Background}

Human T-cell leukemia virus type 1 (HTLV-I) is a complex retrovirus that causes adult T-cell leukemia/lymphoma (ATLL), a CD4 lymphoproliferative disease $[1,2]$. While endemic in Japan, South America, Africa, part of the Middle East and the Carribean, there is an increasing prevalence of HTLV-I seropositivity world wide [1-3]. ATL develops in $2-5 \%$ of HTLV-I-infected individuals after a long latency period of about 20-30 years [4-6]. Different clinical features have resulted in the division of this disease into four clinical subtypes characterized by increasing aggressiveness: smoldering, chronic, lymphoma, and acute ATL [7].

One important marker for the risk of ATL within patients is the percentage of abnormal $\mathrm{T}$ lymphocytes versus normal T lymphocytes within the peripheral blood [8]. Binucleated lymphocytes or lymphocytes containing cleaved/ cerebriform nuclei (also termed "flower" cells) have been observed in blood smears of HTLV-I infected individuals and in ATLL cells [7,9-12]. These cells are representative of aneuploidy or abnormal chromosomal content which develops due to aberrant mitotic divisions [13]. Since aneuploidy has been suggested to contribute to tumorigenesis, there is a growing interest in deciphering the events in late G2/mitosis phase and defects therein that lead to aneuploidy. Additionally, aneuploidy may be associated with an acquired resistance to chemotherapeutic agents such as imatinib or 5-fluorouracil [14]; therefore, therapeutics disrupting aneuploidy development may improve upon current therapies for ATLL patients.

There is also a growing body of evidence to suggest that Tax, a $40 \mathrm{kDa}$ viral oncoprotein encoded by HTLV-I, controls various aspects of cell cycle check points needed for aneuploidy. In fact, we were one of the first groups to show that Tax controls the G1/S check point [15], which was later confirmed by others [16], resulting in failure of G1 checkpoint and NER deficiency [17]. For a more comprehensive review of the cell cycle and check point controls by Tax, we recommend some of the more relevant reviews published recently [18-21]. In addition to disrupting checkpoints at the G1/S resulting in continuous cellular proliferation, Tax also directly targets a number of G2 and mitotic regulators. One of the first indication of Tax's involvement in the G2 and M phases was shown by Jin and colleagues [22] who discovered that Tax binds to hsMAD1. MAD1 and MAD2 are two of several genes that are involved in the activation of the mitotic spindle checkpoint function (MSC) following chromosomal missegregation. Tax interaction hindered the binding of MAD1/ MAD2 complex to kinetochores by inducing translocation of these factors from the nucleus to the cytoplasm [23]. Furthermore, recent reports have demonstrated that Tax promotes activation of the anaphase promoting complex
(APC)- APCCdc20p leading to a reduction in Pds1p/securin and Clb2p/cyclin B levels in yeast, rodent and human cells $[6,24]$. Overall, the degradation of these critical check point proteins results in a delay or failure in mitotic entry and progression, and is accompanied by a loss of cellular viability, resulting in aberrant anaphase progression, chromosomal instability and severe DNA aneuploidy [2527].

Concurrently, Tax has been shown to repress cellular DNA repair by binding to Chk2 $[24,28]$ and Chk1, thus impairing kinase activities in vitro and in vivo [25]. Moreover, Tax silences cellular checkpoints, which guard against DNA structural damage and chromosomal missegregation, thereby favoring the manifestation of a mutator phenotype in cells [18]. In such cells, rapidly induced cytogenetic damage can be measured by a significant increase in the number of micronuclei (MN) in cells knocked-out for DNAPKcs [29,30]. Therefore, it is possible that Tax perturbs many dynamic complexes that coordinate the processes of cell cycle regulation and DNA repair.

Here we present evidence that cytotoxic T cells (CTLL) stably expressing wild type Tax (CTLL/WT) exhibited a higher incidence of aneuploidy when compared to a Tax clone deficient for CREB transactivation (CTLL/703) [31]. Given the role of Tax as a strong activator of both viral and cellular transcription, we address the role of Tax-dependent transcription through the CREB/ATF pathway in the possible development of aneuploidy. We performed gene expression microarray analysis comparing CTLL/WT to CTLL/703 cells. Those genes that were either up or downregulated in CTLL/WT cells were functionally annotated using the NIH's Database for Annotation, Visualization, and Integrated Discovery (NIH-DAVID). Next, we used an online database - PromoSer - to extract promoters of annotated genes to determine which of these genes contained CREB binding sites. Finally, chromatin immunoprecipitation was used to determine if DNA binding proteins such as Tax, Pol II and CREB were present at the promoters of the few selected genes. Our results clearly indicate that Tax/CREB binds to promoters of many genes, including Sgt1 and p97 (Vcp), which have functions in spindle formation and disassembly, respectively. The consequences of their over-expression and involvement in aneuploidy will be discussed.

\section{Results and discussion}

\section{Aneuploidy prevalence in CTLL/WT cells}

Tax deregulates the expression of genes that encode interleukin-2 (IL-2) and the multisubunit (IL-2R alpha, IL-2R beta, and IL-2R gamma) IL-2 receptor (IL-2R) in the early phases of HTLV-I induced ATL [32]. In the later phases of ATL, cells no longer produce IL-2 but still continue to express the IL-2R [32]. Fujii and colleagues developed an 
IL-2 independent system where Tax was stably expressed in a mouse IL-2-dependent T-cell line, CTLL-2, and examined the growth property of these cells in the absence of IL-2 [31]. While the Tax M47 (703) mutant activates NF$\kappa \mathrm{B}$-dependent transcription but not CRE-dependent transcription, the reverse is true for the Tax M22 mutant [31]. They also noted that in addition to Tax's role in cAMPresponsive element (CRE) and NFKB activation pathways, Tax also increases expression of mRNAs coding for various AP-1 transcription factor family members including $c$-Jun, JunB, JunD, c-Fos and Fra-1. Genes encoding AP-1 are immediate-early genes whose products play important roles in cell activation, proliferation and transformation. Thus, an alternate pathway, i.e., AP-1, may be involved in the dysregulated phenotypes of $\mathrm{T}$ cells expressing Tax (CTLL) or infected with HTLV-1 [33].

Initially, these mutants were used to investigate the involvement of the transcription pathways in the transformation of CTLL- 2 cells by Tax. Wild type Tax expression in CTLL-2 cells resulted in IL-2 independent growth. The Tax M47 mutant still activated the NF-кB-dependent transcription, and was able to support the growth of CTLL-2 in the absence of exogenously added IL-2. Therefore, the CREB dependent activity of Tax may not be as critical for IL-2 dependent growth, but may be needed for Tax induced transformation of cells. Tax M47 induced transformation may be accomplished through deregulation of cellular oncogenes, tumor suppressor genes, or checkpoint genes for DNA damage.

Our previous work utilizing these cell lines have shown that depending on which phase of the cell cycle DNA damage occurred, two different phenotypes were observed. Using centrifugal elutriation, we were able to fractionate cells at G1, S, or G2/M based on differences in cell volume at these distinct phases [34]. These cell fractions were gamma irradiated and harvested 24 hrs later for cell cycle analysis by propidium iodide staining and FACS. We observed that the CTLL/WT cells exhibited a distinct phenotype; at G1, these cells were able to induce a G1/S checkpoint, while at S or G2/M phase, these cells apoptosed after gamma irradiation. Conversely, CTLL/703 cells continued to proliferate without any apoptosis. We believed these differences were due, at least in part, to the differing gene expression profile of these cells and the induction of DNA damage at a particular point in the cell cycle. Interestingly, it was also observed that unirradiated CTLL/WT cells displayed a higher prevalence of aneuploidy than CTLL/703. The appearance of aneuploidy occurred in the later fractions (G2/M phase) which represented the largest cell populations. Consistent with our findings, previous reports have also indicated that centrifugal elutriation was capable of separating mixed populations of diploid and aneuploid cells $[35,36]$.
To examine the chromosomal instability in CTLL/WT cells, we first performed a metaphase chromosome spread to determine the average number of chromosomes $[6,37]$. Both CTLL/WT and CTLL/703 cells were processed as described in the Methods section. Thirty-five cells were analyzed for each cell type. As shown in Figure 1, CTLL/ WT cells displayed higher numbers of chromosomes with an average number of 61 in contrast to CTLL/703 cells, where the average number of chromosomes were 44 . The basic karyotype of the Mus musculus species is $2 \mathrm{~N}=40$ [38]. These results support our earlier observation that wild-type Tax expressing cells (CTLL/WT), as compared to the CREB deficient Tax clones (CTLL/703), had a higher incidence of aneuploidy.

Since both of these cells are transformed, i.e. IL-2 independent [31], differences in transformation status cannot explain the presence of aneuploidy in one cell line and not the other. While it is possible that mutation of the Tax protein, resulting in a CREB transactivation deficient Tax (CTLL/703 cells), may disrupt interactions of Tax with late cell cycle checkpoint proteins whose dysregulation contributes to aneuploidy, however, this seems to be an unlikely event. For instance, Tax interaction with hMAD1 (also known as Txbp181) appears to be dependent on the zinc finger motif located within the $\mathrm{N}$-terminus of Tax [22], and not the N-terminal domain as seen in the M47 mutant. Therefore, it appears probable that Tax may contribute to aneuploidy development, at least in part, through transcriptional activation of cellular genes critical for aneuploidy. This result would not be without precedence, since the involvement of Tax in immortalization has been shown to be mediated both at the transcriptional level and by direct protein:protein interactions [18]. Furthermore, since Tax-dependent CREB transactivation was deficient in CTLL/703 and not in CTLL/WT cells (see below), it would appear that those genes involved in aneuploidy development may be CREB-dependent.

\section{Gene expression profiling and promoter analysis}

To begin to examine the contribution of Tax/CREBdependent transcription in aneuploidy development, we compared the transcription profiles of CTLL/WT and CTLL/703 cells by microarray analysis. Our method for comparing the contribution of Tax/CREB to the aneuploidy phenotype is depicted in Figure 2. Through this analysis we obtained a global expression profile of the wild-type Tax-expressing cells as compared to Tax-703 expressing cells and subsequently narrowed our list by determining which genes contained CREB-response elements and potential aneuploidy associated genes. Microarray analysis was performed utilizing cytoplasmic mRNA from both cells and the Affymetrix Murine Genome U74A Array. Analysis was performed in duplicate to minimize inter-chip variability. After normalizing the fluorescence 
A)

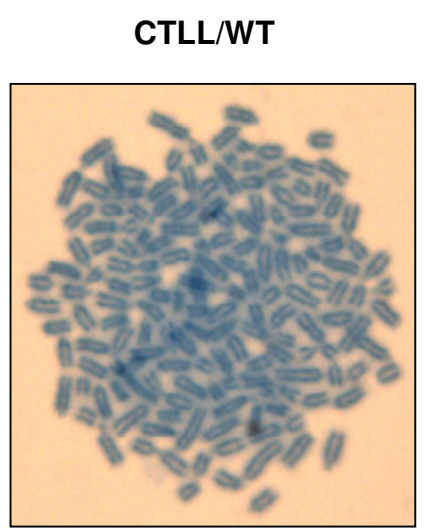

C)

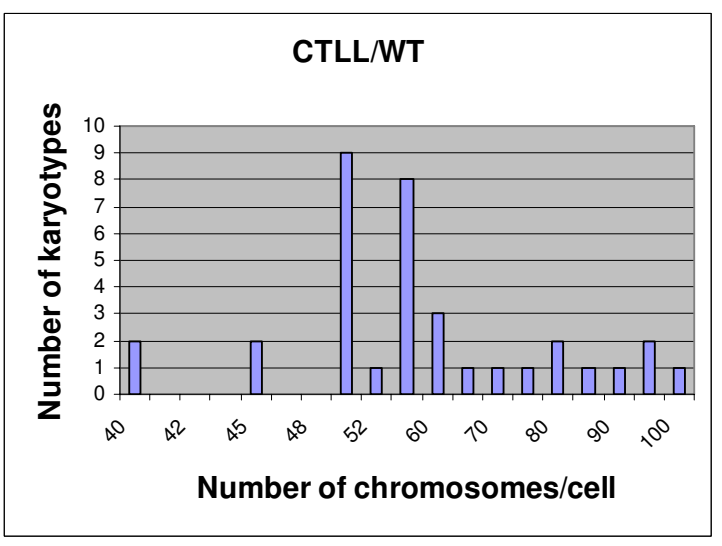

B)

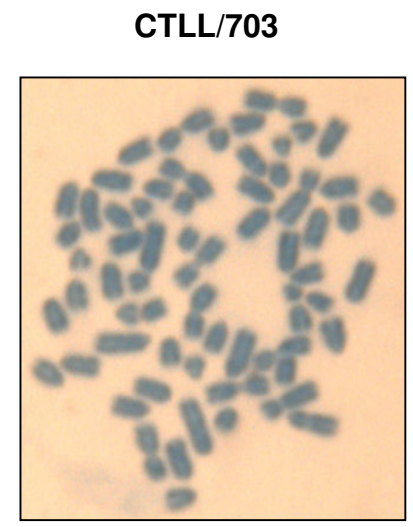

D)

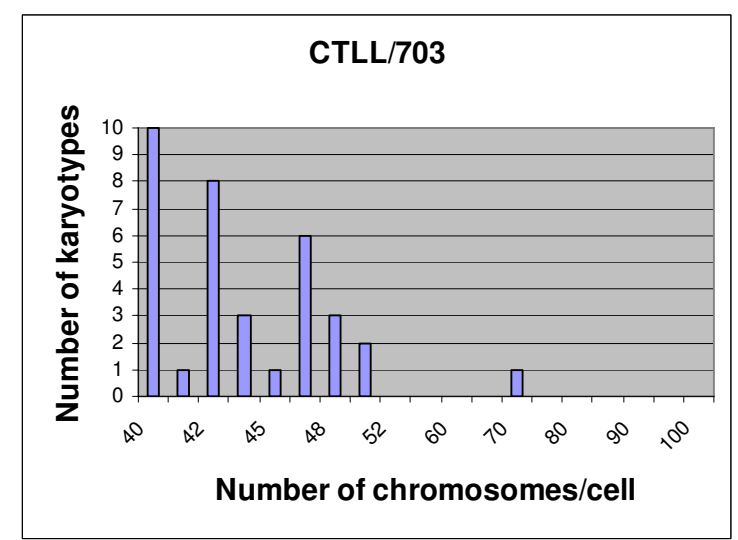

Figure I

Aneuploidy in CTLL/WT cells. CTLL/WT and CTLL/703 cells were treated with $10 \mu g / \mathrm{ml}$ colcemid, centrifuged, and resuspended in hypotonic solution to swell the cells. Cells were then fixed and dropped onto slides. After being stained with Giemsa and dried, slides were analyzed using the Olympus BX-60 microscope. A total of 35 metaphase spreads were counted. Representative chromosome spreads of CTLL/WT (panel A) and CTLL/703 (panel B) are displayed with 100 and 42 chromosomes, respectively. Panels C) and D) are graphical representations of the raw counts from these two cell types.

intensity of each probe and filtering for differentially expressed genes with a difference of at least 2-fold across experiments, a gene list was compiled. These genes were then functionally annotated utilizing the Database for Annotation, Visualization, and Integrated Discovery program (DAVID) [39] to generate a list of 439 genes differentially regulated in CTLL/WT cells [Additional files 1 and $2]$. The majority of these differentially regulated genes were up-regulated in CTLL/WT cells (412 genes increased out of a total of 439 annotated genes, 94\%) and many have been shown to be up-regulated in wild-type, and not in M47, Tax-expressing cells, including p21/waf1 [40], cyclin D2 [15], and Jun B [41], suggesting a correlation between our gene expression profile and previously published results.

Recent studies have utilized microarray analysis to determine whether gene sets were under the control of similar transcription factors by analyzing the promoter sequences for transcription factor binding sites [42-46]. We hypothesized that those genes differentially regulated in CTLL/ WT cells would probably be CREB/ATF-dependent either directly or indirectly. This is based on the assumption that CTLL/703 cells contain mutated Tax, which is unable to transactivate viral or cellular transcription through the CREB/ATF pathway [31]. To determine which promoters 


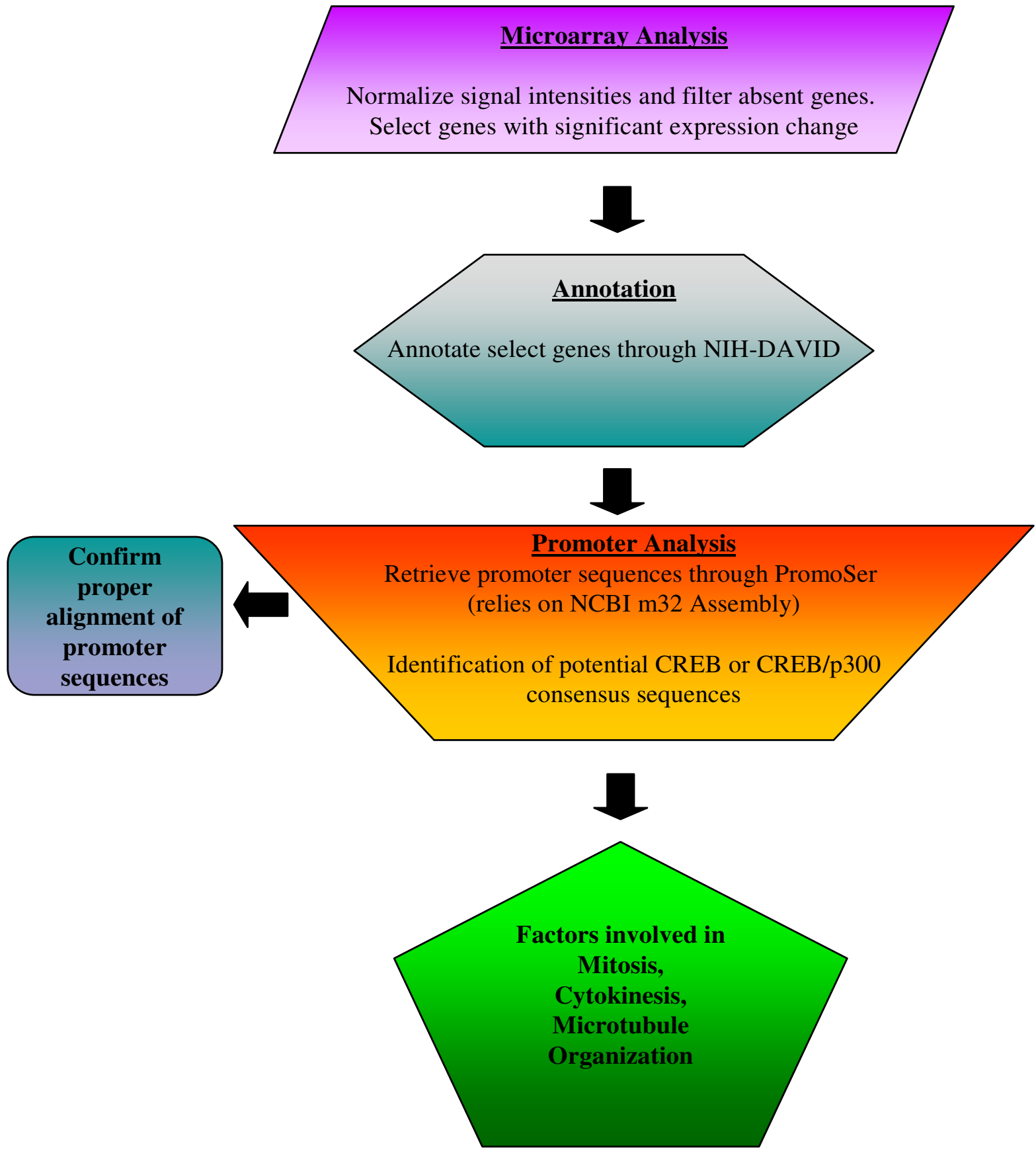

Figure 2

Overview of microarray analysis, annotation, and promoter analysis. A schematic depicting the workflow of the project. Gene expression analysis of CTLL/WT and CTLL/703 cells was performed utilizing the Affymetrix's Murine Genome U74A GeneChip. Genes that were either up-or down-regulated in CTLL/WT cells by a magnitude of at least two-fold were functionally annotated using NIH's DAVID bioinformatics program. Next, promoter sequences (2I00 bp surrounding the predicted TSS) were retrieved from PromoSer. One third of the promoter sequences retrieved were checked for proper alignment against the mouse genome using Blastn and MapViewer tools through NCBI. CREB (TGACGT/C, A/GGGAGT) consensus sequences were obtained through TRANSFAC database and searched within the promoters obtained. Factors that contained the CREB sequences within their promoters were further probed for genes that contribute directly to mitosis, cytokinesis, and microtubule organization. 
were in fact directly CREB/ATF-dependent, we extracted promoter sequences of the differentially expressed mouse genes utilizing PromoSer, a web-based promoter database extraction tool $[47,48]$. This retrieval database utilizes the $\mathrm{mm} 4$ draft release of the mouse genome. Promoter sequences encompassing $2000 \mathrm{bp}$ upstream and $100 \mathrm{bp}$ downstream of the predicted transcription start site (TSS) were retrieved. Of the 439 differentially regulated genes, only 341 promoter sequences could be extracted from the database ( $77 \%$ recovery) under the conditions used. One third of the promoters retrieved were initially compared against the mouse genome using NCBI's Blastn to verify that these sequences were properly aligned. Next, promoter sequences were searched for CREB consensus sequences (obtained through the Transfac database and literature searches [49-52]) to determine which promoters might be CREB-responsive. Interestingly, $28 \%$ of these promoters (95 out of 341 extracted promoter sequences) were found to contain CREB binding sites. These annotated genes with corresponding fold change are depicted in Table 1. Most of the genes identified are involved in a number of pathways including transportation, signaling, cell cycle, transcription and RNA processing, metabolism, stress response, and cytoskeletal protein binding. To determine whether CREB-dependent promoters were preferentially activated, we also performed searches for $\mathrm{NFKB}$ and SRF response elements within the extracted promoters. Both of these transcription factors have been shown to be responsive to Tax [53]. Of these promoters, only $2 \%$ ( 7 out of 341 promoters) were found to contain NFkB recognition sequences and less than $1 \%$ (2 out of 341 promoters) contained SRF sequences (data not shown). Therefore, there was a selective preference in Tax expressing cells to activate CREB-dependent promoters. Through a comprehensive PubMed and DAVID search, we determined which genes were involved in mitosis/cytokinesis and thus were likely candidates to contribute to the development of aneuploidy Table (1).

Several of the candidate genes that may contribute to the development of aneuploidy (Table 2) were found to be associated with and/or regulate kinetochore assembly, including dynactin 3 (Dctn3), protein phosphatase 1, catalytic subunit beta isoform (Ppp1cb), suppressor of G2 allele of SKP1 (Sugt1 or Sgt1), and ZW10 interactor (Zwint-1). Kinetochores are multi-subunit complexes (over 70 proteins in yeast kinetochores alone) that assemble on centromeric DNA and during mitosis act as the attachment site of chromosomes to the microtubules of the mitotic spindle [54-56]. The kinetochore, in addition to engaging microtubules, promotes correct attachment and corrects errors in attachment [57]. During metaphase, the centromeres of replicated sister chromatids are oriented on the spindle apparatus. In a dynamic interaction, the kinetochore associated microtubules associate with constant oscillatory movements until all chromosomes are bi-oriented at the metaphase plate.

While depletion of these particular factors have been shown to cause aneuploidy, over-expression of these factors may prove to be equally problematic. There are instances where over-expression of kinetochore or associated proteins such as dynamitin (p50; [58]), CENP-H [59], and CENP-A [60] led to disruption of the dynactin or kinetochore complex. In the case of CENP-H, overexpression contributed to the appearance ofaberrant micronuclei, a sign of aneuploidy. Therefore we envision a similar scenario where over-expression of dynactin 3 (p24), whichacts as a light-chain subunit of the dynactin complex that tethers microtubules to the kinetochore and was found to bepresent stoichiometrically at one molecule per complex, leads to sequesteration of other components of the dynactin complex away from microtubules leading to aneuploidy.

\section{In vivoconfirmation of CREB binding sites}

Chromatin immunoprecipitation (ChIP) has been used to determine if specific proteins bind to regions of a genome in vivo [61], to identify transcription factor binding to promoters $[62,63]$, and to identify the binding of modified proteins to DNA in vivo $[64,65]$. To confirm that genes regulating aneuploidy were in fact transcriptionally activated in a CREB-dependent manner, a ChIP assay was performed on a few of the Tax regulated genes in CTLL cells. Sgt 1 and p97 were amongst the list of the genes identified based on the presence of potential binding sites for CREB. Sgt 1 has been shown to be an essential protein and a critical assembly factor for kinetochore assembly [66]. Experiments have been carried out in the past to demonstrate the functional significance of Sgt1. RNAi mediated Sgt1 depletion in HeLa cells leads to mitotic delay due to activation of the spindle checkpoint. Sgt1 depletion also led to the reduction in kinetochore levels of three MSC components - Mad1, Mad2 and BubR1 [66].

As shown in Figure 3A, the results from an initial ChIP assay demonstrated that RNA Polymerase II (Pol II) was present at the promoter for Sgt1 in CTLL/WT and not in CTLL/703 cells. This indicated that Pol II was not recruited in the Tax mutant CTLL/703 cells and that the Sgt 1 promoter in CTLL/WT cells was transcriptionally active. Histone H3- phosphorylated serine 10 (denoted as H3S10) was used as a positive control for our ChIP assay in CTLL/ WT and CTLL/703 cells. To determine whether CREB bound in vivo to the promoters of Sgt 1 and $\mathrm{p} 97 / \mathrm{Vcp}$ genes, we utilized CREB and phosphorylated CREB (active form of CREB, denoted as p-CREB) antibodies. Results from the ChIP assay for the promoters of Sgt 1 and p97/Vcp are shown in Figure 3B. Pol II recruitment was used as a positive control. While CREB, p-CREB and Pol II were present 


\begin{tabular}{|c|c|c|c|c|c|c|c|c|c|c|c|c|}
\hline $\begin{array}{l}\text { Genbank } \\
\text { Accession } \\
\text { Number }\end{array}$ & & Gene & $\begin{array}{c}\text { Fold } \\
\text { Change }\end{array}$ & $\begin{array}{c}\text { Transcription/ } \\
\text { RNA } \\
\text { Processing }\end{array}$ & Peptidase & $\begin{array}{l}\text { Cytoskeletal } \\
\text { Protein } \\
\text { Binding }\end{array}$ & Transport & M etabolism & $\begin{array}{l}\text { Transm } \\
\text { em brane } \\
\text { Receptor }\end{array}$ & Signaling & $\begin{array}{l}\text { Cell } \\
\text { Cycle }\end{array}$ & $\begin{array}{c}\text { Stress } \\
\text { Response }\end{array}$ \\
\hline AF06407I & Apafl & $\begin{array}{l}\text { a po pto tic protease } \\
\text { activating factor I }\end{array}$ & 2.5 & & $\mathbf{x}$ & & & & & & & \\
\hline D87898 & Arfl & ADP-ribosylation factor I & 2.6 & & & & $\mathbf{x}$ & & & $\mathbf{x}$ & & \\
\hline$\overline{\mathrm{BC} 010700}$ & Atp5cl & $\begin{array}{l}\text { ATP synthase, } \mathrm{H}^{+} \\
\text {transporting, } \mathrm{m} \text { itochondrial } \\
\text { FI com plex, gam m a } \\
\text { polypeptide I }\end{array}$ & 2.1 & & & & $\mathbf{x}$ & & & & & \\
\hline NM 009729 & Atp6r0c & $\begin{array}{l}\text { ATPase, } H+\text { transporting, } \\
\text { V0 subunit } C\end{array}$ & 2.3 & & & & $\mathbf{x}$ & & & & & \\
\hline AFI83960 & Ccrn4l & $\begin{array}{l}\text { CCR4 carbon catabolite } \\
\text { repression 4-like (S. } \\
\text { cerevisiae) }\end{array}$ & 2.1 & & & & & & & & $\mathbf{x}$ & \\
\hline BC054097 & Cetn3 & centrin 3 & 2.2 & & & & & & & & $\mathbf{x}$ & \\
\hline AF016583 & ChekI & $\begin{array}{l}\text { checkpoint kinase I } \\
\text { homolog (S. pom be) }\end{array}$ & 2.3 & & & & & & & $\mathbf{x}$ & $\mathbf{x}$ & \\
\hline NM 009942 & Cox5b & $\begin{array}{l}\text { cytochrom e c oxidase, } \\
\text { subunit } \mathrm{Vb}\end{array}$ & 2.3 & & & & $\mathbf{x}$ & & & & & \\
\hline BC010197 & Cpe & carboxypeptidase E & 17.3 & & $\mathbf{x}$ & & & & & & & \\
\hline$\underline{\mathrm{U} 73445}$ & Did & $\begin{array}{l}\text { dihydrolipoam } \\
\text { idedehydrogenase }\end{array}$ & 2.4 & & & & $\mathbf{x}$ & & & & & \\
\hline NM 007897 & Ebfl & early B-cell factor I & 2.9 & $\mathbf{x}$ & & & & & & & & \\
\hline$\overline{D 43689}$ & $\mathrm{FdxI}$ & ferredoxin I & 4.3 & & & & $\mathbf{x}$ & & & & & \\
\hline A| 534939 & Sm c2II & $\begin{array}{l}\text { SM C2 structural } \\
\text { maintenance of } \\
\text { chromosomes 2-like I } \\
\text { (yeast) }\end{array}$ & 2.8 & & & & & & & & $\mathbf{x}$ & \\
\hline $\mathrm{AB} 093214$ & Lpin I & lipin I & 2.4 & & & & & $\mathbf{x}$ & & & & \\
\hline NM 010239 & Fth & ferritin heavy chain & 2.4 & & & & $\mathbf{x}$ & & & & & \\
\hline AF024620 & Gabrrl & $\begin{array}{l}\text { gam } m \text { a-am inobutyric acid } \\
\text { (GABA-C) receptor, } \\
\text { subunit rho I }\end{array}$ & 2.3 & & & & $\mathbf{x}$ & & $\mathbf{x}$ & $\mathbf{x}$ & & \\
\hline M63801 & Gjal & $\begin{array}{l}\text { gap junction } m \text { em brane } \\
\text { channel protein alpha I }\end{array}$ & 7.4 & & & & & & & & & \\
\hline NM 010306 & Gnai3 & $\begin{array}{l}\text { guanine nucleotide binding } \\
\text { protein, alpha inhibiting } 3\end{array}$ & 2.0 & & & & & & & $\mathbf{x}$ & & \\
\hline BC005683 & Grcclo & gene rich cluster, $\mathrm{ClO}$ gene & 2.2 & & & & & & & $\mathbf{x}$ & & \\
\hline NM 022310 & Hspa5 & $\begin{array}{l}\text { heat shock } 70 \mathrm{kD} \text { protein } 5 \\
\text { (glucose-regulated protein) }\end{array}$ & 3.0 & & & & & & & & & $\mathbf{x}$ \\
\hline$\underline{\mathrm{U} 53514}$ & GukI & guanylate kinase I & 4.2 & & & & & $\mathbf{x}$ & & & & \\
\hline M21931 & $\mathrm{H} 2-\mathrm{Aa}$ & $\begin{array}{l}\text { histocom patibility } 2 \text {, class II } \\
\text { antigen A, alpha }\end{array}$ & 3.8 & & & & & & $\mathbf{x}$ & & & \\
\hline BC010322 & $\mathrm{H} 2-\mathrm{Abl}$ & $\begin{array}{l}\text { histocom patibility } 2 \text {, class II } \\
\text { antigen A, beta I }\end{array}$ & 3.1 & & & & & & $\mathbf{x}$ & & & \\
\hline
\end{tabular}


Table I: Cellular genes containing CREB response element activated by Tax (Continued)

\begin{tabular}{lll}
\hline M58595 & H2-DI & $\begin{array}{l}\text { histocom patibility 2, D } \\
\text { region locus I }\end{array}$ \\
& & 2.7
\end{tabular}

region locus I

U35330 H2-DM bl histocom patibility 2, class II, $\quad 2.5$

locus $\mathrm{M}$ bl

NM 013820 Hk2 hexokinase 2 2.5

BC052727 Hspa9a heat shock protein, A

M5982I ler2 im m ediate early response 2.9

103236 Junb

NM 010724 Psm b8

Jun-B oncogene

2.0

proteosome (prosom e, 2.6

macropain) subunit, beta

type 8 (large $\mathrm{m}$

ultifunctional protea

m alate dehydrogenase $2, \quad 3.4$

$\begin{array}{ll}\text { AY176058 Nfkbib } & \text { NAD (m itochondrial) } \\ \text { nuclear factor of kappa light }\end{array}$

chain gene enhancer in B-

cells inhibitor, beta

AF026124 PId3 phospholipase D3

BC046832 Ppplcb protein phosphatase I,

catalytic subunit, beta

isoform

NM 011186 Psm b5 proteasome (prosome

2.3

type 5

D879|I Psm e3 proteasome (prosome, 2.2

$\begin{array}{lll}\mathbf{X} 61940 & \text { macropain) } 28 \text { subunit, } 3 \\ \text { dual specificity phosphatase } & 8.1\end{array}$

dual specificity phosphatase 8.1

purine rich elem ent binding $\quad 2.4$

protein A

NM 008989 Pur

BC026915 Rab6 RAB6, $m$ em ber RAS 2.4

oncogene fam ily

$\underline{\text { U67187 Rgs2 }} \quad$ regulator of G-protein

signaling 2

AF065924 Ccll chem okine (C-C m otif) 0.3

ligand I

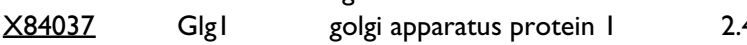

$\underline{\mathrm{BC} 034674}$ Slc3lal solute carrier fam ily 31, 2.9

mem ber I

BC021537 Srpl4 signal recognition particle

14

BC028507 Tnfrsf9 tum or necrosis factor

receptor superfam ily,

member 9

AFI59593 Plscrl phospholipid scram blase I $\quad 5.2$

AF033353 Ubll ubiquitin-like I

AY162409 Vwf Von W illebrand factor 2.3

homolog

$\mathbf{x}$

$\mathbf{x}$

$\mathbf{x}$

$\mathbf{X}$

$\mathbf{x}$

$\mathbf{x}$

X 
Table I: Cellular genes containing CREB response element activated by Tax (Continued)

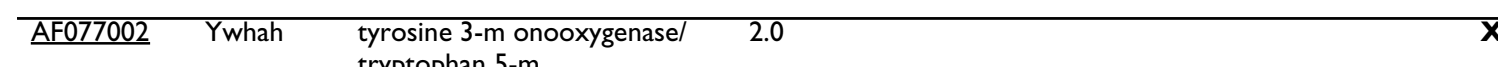

tryptophan 5-m

onooxygenase activation

protein, eta po

U77667 Zap70 $\quad \begin{aligned} & \text { zeta-chain (TCR) associated } \\ & 2.6\end{aligned}$

protein kinase

BC005589 Cfdp craniofacial development 2.1

protein I

ATP synthase, $\mathrm{H}^{+}$

transporting, $m$ itochondrial

BC014798 Taxlbpl FI com plex, O subunit

leukemia virus type I)

binding protein I

AF40665I Hnrpa2bI heterogeneous nuclear 2.5

ribonucleoprotein $\mathrm{A} 2 / \mathrm{B}$

AF098508 Dctn3 dynactin $3 \quad 2.4$

$\underline{\mathrm{AFI} 133818} \quad$ Zfp265 zinc finger protein $265 \quad 2.1$

$\begin{array}{llll}\underline{\mathrm{BC} 037732} & \text { Rragc } & \text { Ras-related GTP binding C } & 2.7\end{array}$

AFI48447 Uchl5 ubiquitin carboxyl-terminal 2.3

esterase L5
destrin

$\begin{array}{llll}\mathrm{AB} 025406 & \text { Dstn } & \text { destrin } & 2.6 \\ \underline{\mathrm{BC} 002126} & \text { Gabarap } & \text { gam m a-am inobutyric acid } & 2.1\end{array}$

gam $m$ a-am inobutyric acid
receptor associated protein

$\underline{B C 018430}$ Asnal arsA (bacterial) arsenite

transporter, ATP-binding,

hom olog I

$\underline{\mathrm{ABO} 05652} \quad$ Park7 $\quad \begin{aligned} & \text { Parkinson disease } \\ & \text { (autosomal recessive, early }\end{aligned}$

onset) 7

$\begin{array}{lll}\mathrm{BC} 02275 \mathrm{I} & \operatorname{lsg} 20 \quad \text { interferon-stimulated } & 4.8\end{array}$

protein
vacuolar protein sorting $35 \quad 2.3$

$\begin{array}{llll}\text { BC005469 } & \text { Vps35 } & \text { vacuolar protein sorting 35 } & 2.3 \\ \text { BC005620 } & \text { Cycl } & \text { cytochrom e c-I } & 2.2\end{array}$

$\underline{\mathrm{BC} 024355}$ Usm g5 upregulated during skeletal 2.2

$\mathrm{m}$ uscle growth 5

$\underline{\mathrm{BC} 051934} \mathrm{Sdhb}$

succinate dehydrogenase

(iron

sulfur (IP)

BC009167 SugtI SGTI, suppressor of G2 
Table I: Cellular genes containing CREB response element activated by Tax (Continued)

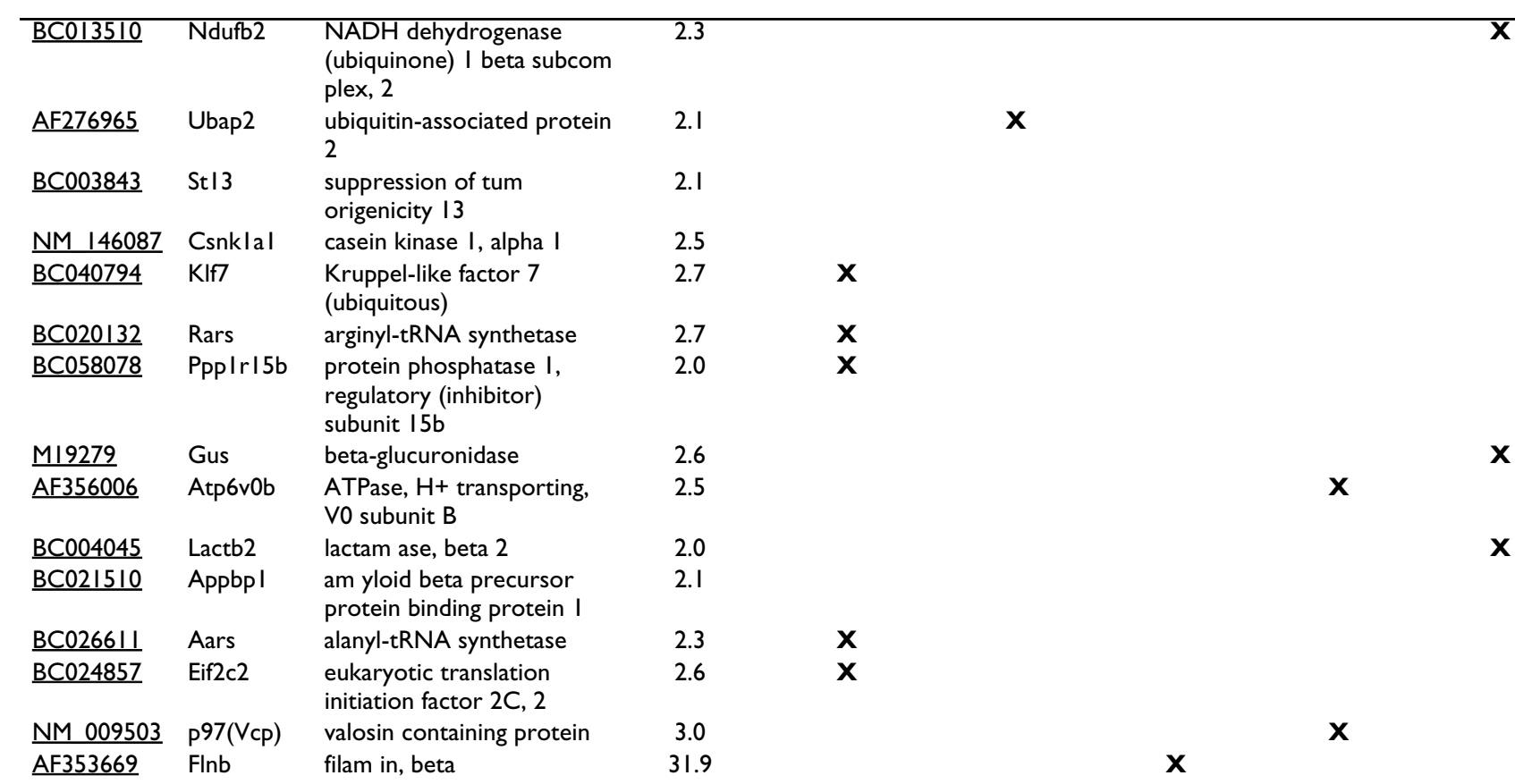

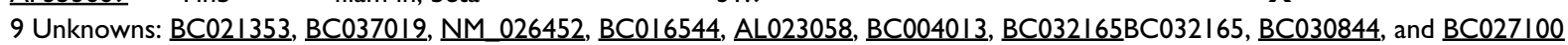


Table 2: Tax activated genes involved in aneuploidy

\begin{tabular}{|c|c|c|c|c|}
\hline $\begin{array}{l}\text { Genbank } \\
\text { Accession } \\
\text { Number }\end{array}$ & Gene & & Fold change & Function \\
\hline D87898 & Arfl & ADP-ribosylation factor I & 2.6 & $\begin{array}{l}\text { Membrane vesicle formation, inactivation nec. for mitotic } \\
\text { Golgi breakdown, chromosome segregation, and } \\
\text { cytokinesis [95-97] }\end{array}$ \\
\hline$\underline{\mathrm{BC} 054097}$ & Cetn3 & centrin 3 & 2.2 & $\begin{array}{l}\text { spindle cell body duplication need for bipolarity in } \\
\text { cytokinesis [98-103] }\end{array}$ \\
\hline AF016583 & Chekl & $\begin{array}{l}\text { checkpoint kinase I homolog } \\
\text { (S. pombe) }\end{array}$ & 2.3 & $\begin{array}{l}\text { needed for S and G2 checkpoints after DNA damage; Tax } \\
\text { has been shown to disrupt its function }[24,25,104-106]\end{array}$ \\
\hline$\underline{\mathrm{AF} 098508}$ & Dctn3 & dynactin 3 & 2.4 & $\begin{array}{l}\text { light-chain subunit of dynactin complex (p24); dynactin } \\
\text { complex involved in vesicle movement; dynactin complex } \\
\text { interacts with NuMA and dynein in order to tether } \\
\text { microtubules at the spindle poles and that are essential for } \\
\text { mitotic spindle pole assembly and stabilization; recruitment } \\
\text { by ZWI0 protein to the kinetichore [107-I I0] }\end{array}$ \\
\hline NM 009503 & p97(Vcp) & valosin containing protein & 3.0 & $\begin{array}{l}\text { aka cdc48; needed for spindle disassembly after } \\
\text { segregation; Golgi disassembly-assembly [III-| I3] }\end{array}$ \\
\hline$\underline{\mathrm{BC}} 046832$ & Ppplcb & $\begin{array}{l}\text { protein phosphatase I, catalytic } \\
\text { subunit, beta isoform }\end{array}$ & 2.5 & $\begin{array}{l}\text { antagonist of Aurora B kinase during mitosis, i.e. regulating } \\
\text { the protein interface between the centromeres and the } \\
\text { mitotic spindle; possible downstream targets include } \\
\text { kinetochore protein Ndc I0, CENP-A, which substitutes } \\
\text { for histone H3 in centromeric nucleosomes, and inner } \\
\text { centromere protein INCENP; mutation of PPI or } \\
\text { inactivation was shown to result in cytokinesis defects. } \\
{[1 \mid 4]}\end{array}$ \\
\hline NM 008989 & Pura & purine rich element binding protein $A$ & 2.4 & $\begin{array}{l}\text { involved in DNA replication and transcription; } \\
\text { overexpression results in } G 2 \text { blockage }[115,116]\end{array}$ \\
\hline Al534939 & Smc2II & $\begin{array}{l}\text { SMC2 structural maintenance of } \\
\text { chromosomes 2-like I (yeast) }\end{array}$ & 2.8 & $\begin{array}{l}\text { aka CAP-E protein, that is part of the condensin protein } \\
\text { complex originally identified in Xenopus; protein complex } \\
\text { is needed for chromosome condensation; CAP-E has been } \\
\text { found to interact with DNA ligase IV (DNA double-strand } \\
\text { break repair protein) possible interaction important for } \\
\text { genome stability [II7-120] }\end{array}$ \\
\hline$\underline{B C 009167}$ & Sugtl & $\begin{array}{l}\text { SGT I, suppressor of G2 allele of SKPI } \\
\text { (S. cerevisiae) }\end{array}$ & 2.3 & $\begin{array}{l}\text { recent study shows that SGTI is needed for kinetechore } \\
\text { assembly }[66,76]\end{array}$ \\
\hline AF077002 & Ywhah & $\begin{array}{l}\text { tyrosine } 3 \text {-monooxygenase/ } \\
\text { tryptophan } 5 \text {-monooxygenase } \\
\text { activation protein, eta polypeptide }\end{array}$ & 2.0 & $\begin{array}{l}\text { binds to } C D C 25 B \text { in a phosphorylation independent } \\
\text { mechanism }[121,122]\end{array}$ \\
\hline$\underline{\mathrm{BC} 027100}$ & Zwint-I & ZWIO interactor & 2.1 & $\begin{array}{l}\text { specifies the kinetochore association of ZWIO which may } \\
\text { act as part of, or immediately downstream of, the wait } \\
\text { anaphase tension-sensing checkpoint }[123,124]\end{array}$ \\
\hline
\end{tabular}

at the Sgt 1 promoter in CTLL/WT cells, we only observed the presence of CREB and not p-CREB or Pol II at this promoter in CTLL/703 cells (top right and left panels). This suggested that in CTLL/WT cells there was an active recruitment of the transcription machinery on the Sgt1 promoter. Furthermore, the presence of a phosphorylated CREB on this promoter is an indication of an active transcriptional complex [67]. We next performed similar experiments for the $\mathrm{p} 97 / \mathrm{Vcp}$ promoter and observed the presence of CREB and Pol II at the proximal promoter region in the CTLL/WT cells. Interestingly, we observed no p-CREB binding (always similar levels to the background beads) in CTLL/WT cells. A different scenario emerged in the CTLL/703 cells, where only Pol II, and not CREB or pCREB were present at this promoter, indicating that in the absence of Tax and CREB, there might be a paused tran- scriptional complex on this promoter (Figure 3B, bottom right and left panels).

A graphical representation for the same ChIP results from Figure 3 were plotted using Phosphor Imager counts (Figure $4 \mathrm{~A}$ and $4 \mathrm{~B}$ ), where less CREB binding was observed in the CTLL/703 as compared to the CTLL/WT cells. Additionally, Pol II recruitment was found to be higher in CTLL/WT than in CTLL/703 cells. The increased recruitment of both CREB and Pol II in wild-type Tax-expressing cells, supports the hypothesis that Tax increases (either directly or indirectly) the expression of these genes.

Finally, we performed two confirmatory assays for the up regulation of these gene products by Tax. Results in Figure $5 \mathrm{~A}$ show western blots from two wild-type Tax expressing 
A)

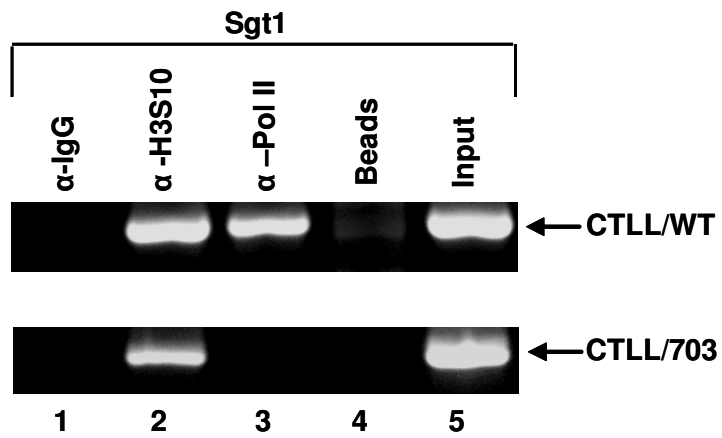

B)
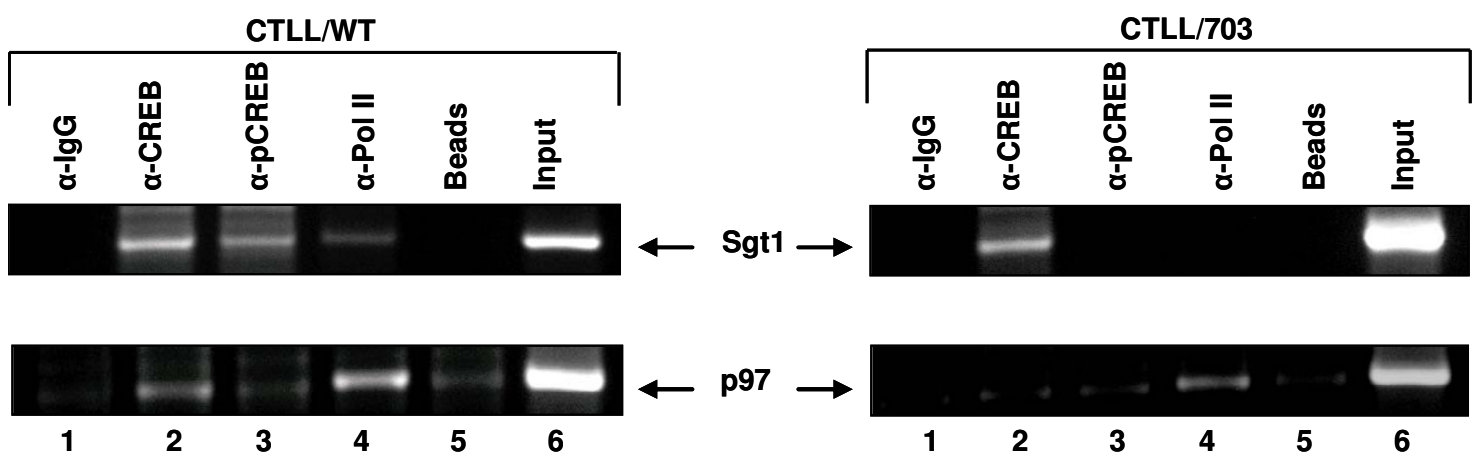

Figure 3

Recruitment of CREB and basal transcription machinery at the Sgtl and p97/Vcp promoters. A) Presence of Pol II on Sgt I promoter. ChIP analysis of Sgt I promoter using IgG, anti- H3SIO, and anti- Pol II antibodies ( $\alpha$-RNAP II, Santa Cruz, polyclonal rabbit \#N-20)compared to input (lanes I, 2, 3 and 5, respectively). IgG and beads only (lanes I and 4) were used as negative controls. Top panel corresponds to typical results from CTLL/WT cells, while the bottom panel corresponds to results from CTLL/703 cells. B) Presence of CREB and Pol II on Sgtl and p97 promoters. ChIP analysis of Sgt I and p97/Vcp promoters using antibodies against CREB, p-CREB and Pol II (lanes 2, 3 and 4). The Pol II antibody recognizes the phosphorylated elongating Pol II complex ( $\alpha$-Ser 2P CTD (H5, Covance)). IgG and Beads alone (lanes I and 5) were used as negative controls.

cells (C81 and CTLL/WT), mutant Tax expressing cells (CTLL/703), and one negative control (CEM). When examining for Sgt 1 levels, we observed two forms of this protein in human cells ( $\mathrm{A}$ and $\mathrm{B}$ ), where the $\mathrm{A}$ form is the original gene product and the $\mathrm{B}$ form is a splice variant [68]. Interestingly, the A form was predominantly seen in both wild type Tax expressing human and mouse cells. When examining p97 levels, we observed more pronounced activation in human cells (panel A, Lanes 1 and
2) as compared to the mouse cells. Similar levels of Tax were present in both CTLL/WT and CTLL/703 cells (data not shown). We next examined the effect of Tax on endogenous Sgt1 and p97 promoters in human cells. Results from Figure 5B indicate that only wild type and not the M47 mutant was capable of activating both Sgt 1 and p97 genes in vivo. This is critical because transfection with Sgt1 and $\mathrm{p} 97$ promoters may not have all the necessary elements (i.e. chromatin structure, enhancer-less promoter, 
A)

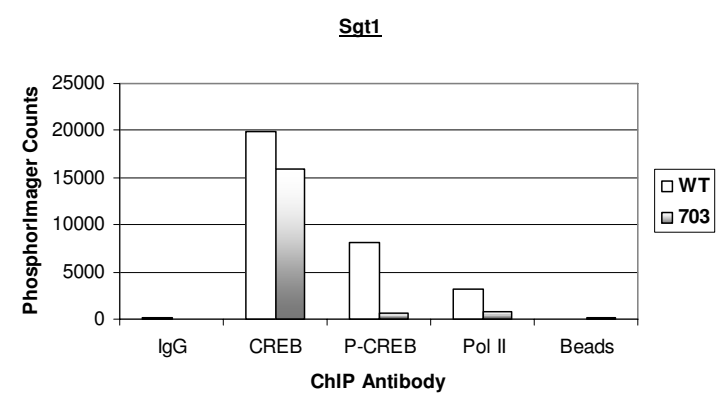

B)

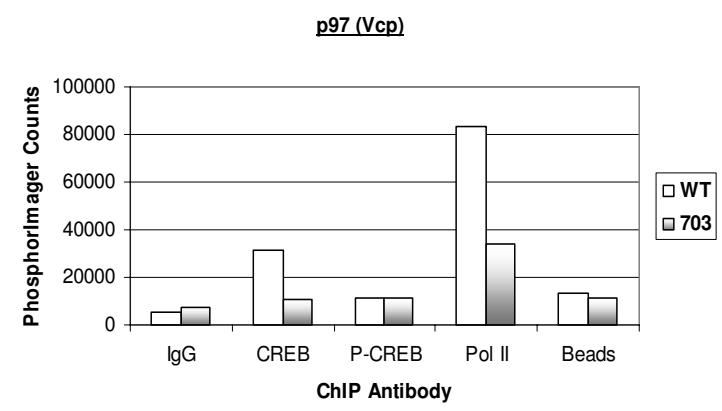

Figure 4

Sgt I and p97 ChIP results. A) and B) are the graphical representations of the Sgtl and $\mathrm{p} 97 \mathrm{ChIP}$ results obtained from CTLL/WT and CTLL/703 cells shown in Figure 3 (Average of two experiments).

proper promoter start site, and promoter distance in relation to the gene) needed to observe activated transcription by Tax in vivo.

\section{Direct effect of Tax on gene promoters}

An important question is whether Tax affects the expression level of genes listed in Tables 1 or 2 or alternatively, does Tax directly interact with any of these proteins and subsequently control aneuploidy. Although, we couldn't logistically design experiments to test all the genes listed in Tables 1 or 2 for promoter occupancy by Tax or direct protein-protein interaction, we decided to focus on the same two Sgt1 and p97 genes tested previously. We initially performed a ChIP experiment for the presence of Tax (using four $\mathrm{TAb}$ monoclonal antibodies) on these two promoters. Results in Figure 6A indicate that only WT, and not M47 mutant, Tax was present on both Sgt1 and p97 promoters (compare lanes 2, 5 and 8). Interestingly, we could always observe presence of more Tax on Sgt1 than p97 promoter. However, the presence of more Tax didn't correlate with increased expression levels for these two promoters (fold activation by Tax: Sgt1, 2.3 fold; p97, 3.0 fold). Next, we asked whether Tax could physically bind to either Sgt1 or p97 proteins in either an unsynchronized culture system (where the majority of cells are at the G1 phase) or cells enriched in the G2/M phase. We used human C81 cells for these immunoprecipitations followed by a high salt wash and western blot for Tax. We have previously used this stringent wash condition to identify some of the Tax binding proteins in C81 cells [69]. Results (Figure 6B) indicate that Tax could physically bind to cdk2 (positive control) and not Sgt1 or p97 proteins. It is important to note that we favor high salt washes for Tax immunoprecipitations, since low salt wash conditions may not dissociate tightly bound complexes. Collectively, results in Figure 6 indicate that Tax directly activates some of the critical proteins needed for development of aneuploidy, although with the caveat that our experimental procedures cannot fully rule out the possibility of direct protein-protein interaction between Tax and complexes that regulate aneuploidy in transformed cells.

Finally, given our results in Table 2, we wondered how over-expression of some of these genes by Tax could contribute to aneuploidy? A careful examination of the p97 and Sgt1 literature indicates that when these proteins are over-expressed, they deregulate control of few cellular pathways including apoptosis, cell division, and cell cycle. For instance, over-expression of p97 in Tax expressing cells could exhibit multiple functions including a role in anti-apoptosis and metastasis by activation of the NFKB signaling pathway [70], as well as its binding to Cdc48 and its adaptors, Ufd1-Npl4. Cdc48 and Ufd1-NPl4 regulate membrane related functions and mitotic spindle disassembly by directly binding to membrane-associated proteins or spindle assembly factors, modulating their interactions with membranes or spindles, respectively. The AAA ATPase CDC48 was first identified in Saccharomyces cerevisiae as a cell cycle division gene. Cdc48, as well as its homolog p97 in vertebrates, forms a homohexameric ring that functions as an active ATPase. Together with its adaptor proteins, the Ufd1-Npl4 heterodimer, the Cdc48/p97-Ufd1-Npl4 complex participates in a variety of membrane-related functions, including morphological transformations in cell division, particularly in establishing a proper G1 phase after mitosis. Consistent with this idea, Cdc48/p97-Ufd1-Npl4 is required for post-mitotic nuclear envelope reassembly [71], one of the major morphological transformations occurring at the end of cell division.

Over-expression of the Cdc48/p97-Ufd1-Npl4 complex could also assist in modification of chromatin by removing proteins involved in chromosome condensation from the highly condensed mitotic chromatin. In addition, this complex may directly regulate nuclear envelope assembly by assisting proper assembly of nuclear envelope proteins on the chromatin, which puts the proteins at the right place to coordinate post-mitotic chromosome deconden- 
A)

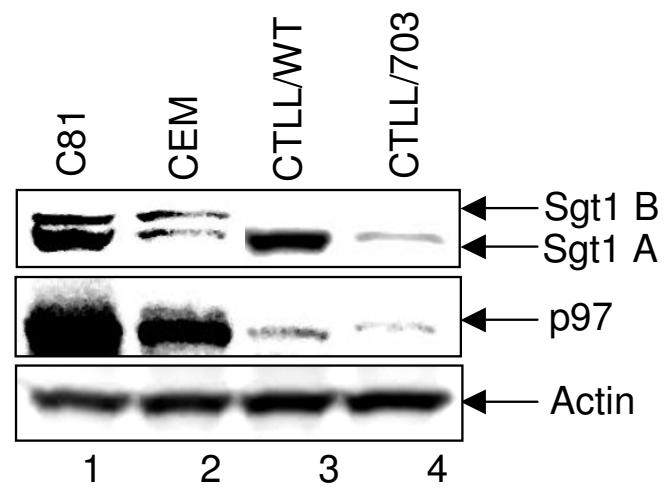

B)

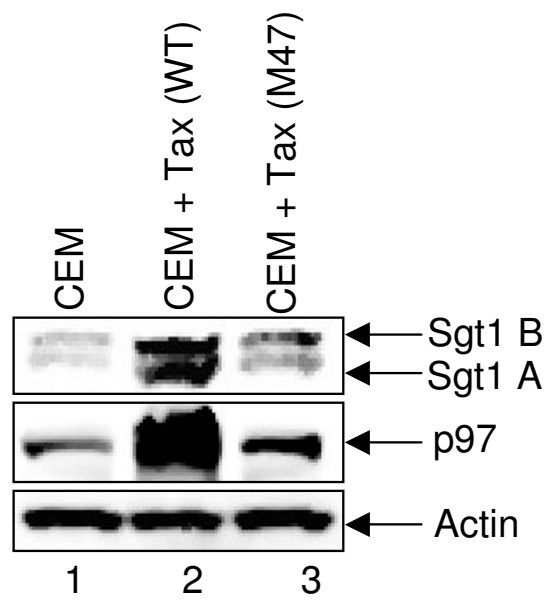

\section{Figure 5}

Effect of Tax on Sgtl and p97 protein levels. A) One hundred microgram of total cell extracts from human (CEM and C8I) and mouse (CTLL/WT and CTLL/703) cells were prepared and ran on a 4-20\% SDS PAGE. All three C8I, CTLL/WT, CTLL/703 express Tax and CEM served as a negative control. Western blots were with anti-SgtI (I:I000), anti-p97 (I:500) and anti-actin (I:5000) antibodies. Two forms of Sgtl (A and B) were observed in human cells, where the A form is wild type protein and B form is the splice variant. B) Five microgram of either wild type or M47 Tax was transfected into CEM (5x 06/ sample) cells. Following transfection cells were kept at $37^{\circ} \mathrm{C}$ for $48 \mathrm{hrs}$, followed by preparation of total extract and processed for western blot using a 4-20\% SDS-PAGE. Similar antibodies as in panel A were used for the western blot and immune complexes were detected using ECL.

sation with nuclear envelope assembly [72]. A third function of over-expressed p97 could be its role with Cdc48 and the execution of "Start" in G1 by mediating the proteolysis of the G1-CDK inhibitors i.e., Far1 [73]. This would be consistent with the idea that Cdc48/p97-Ufd1-Npl4 has a general role in regulating proper M-G1 transition [72]. Finally, over-expressed p97 ATPase could extract class I MHC from ER membranes [74]. Polyubiquitinated substrates preferentially bind by p97 ATPase in complex with two adaptor proteins, Ufd 1 and Npl4. This association triggers retrotranslocation of the substrates from the ER membrane, followed by proteasome-mediated degradation [75].

Increased expression of Sgt 1 induced by Tax could also affect the dynamics of its many protein partners resulting in efficient substoichiometric complexes. Sgt1 (TPR+CS domain) binds to Skp1 and this interaction might play a role in activation of multiprotein complexes CBF3 and SCF [76], assembly of the CBF3 complex, its turnover, and influence proper kinetochore function [77]. Sgt1 (TPR+CS domain) binds to Ctf13 and this binding might influence proper CBF3 assembly [78]. Sgt1 also binds Rad6, which is involved in DNA repair and protein degradation as well as cell cycle progression [79]. Furthermore, Sgt1p contributes to the activity of the cyclic AMP (CAMP) pathway and physically interacts with the adenylyl cyclase Cyr1p/ Cdc35p, where a G $\alpha$ subunit-type protein called Gpa2p and the GTP binding Ras proteins both of which are implicated in adenylyl cyclase activation [80-83]. The major effector of CAMP in eukaryotes is the cAMP dependent protein kinase, or protein kinase A (PKA) [84]. In the absence of cAMP, the catalytic subunit of PKA is found in an inactive complex with the regulatory subunit. The binding of cAMP by the regulatory subunit leads to dissociation of the complex and activation of the catalytic subunit [85]. In budding yeast, the adenylyl cyclase pathway is notably involved in cell growth control and stress responses [80], and also regulates the cell cycle by modulating G1 cyclin expression [86-88] and the activities of the anaphase-promoting complex/cyclosome and the SCF pathway [89].

Therefore, given the role of Sgt 1 in several different types of multimeric protein complexes, it is possible that it acts as some sort of protein chaperone, assembly factor, or allosteric activator. This hypothesis is consistent with structure predictions suggesting that the Sgt $1 \mathrm{~N}$-terminal region is similar to the TPR regions of the Sti1/Hop cochaperone and the central CS domain adopts a fold similar to that of the p23 co-chaperone. Sti1/Hop facilitates protein substrate transfer from Hsp70 to Hsp90, whereas p23 stimulates the ATPase activity of Hsp90 and the release of bound substrate [90]. Finally, several experimental observations are also consistent with a role for Sgt 1 as a co-chaperone or assembly factor. First, Sgt 1 is 
A)

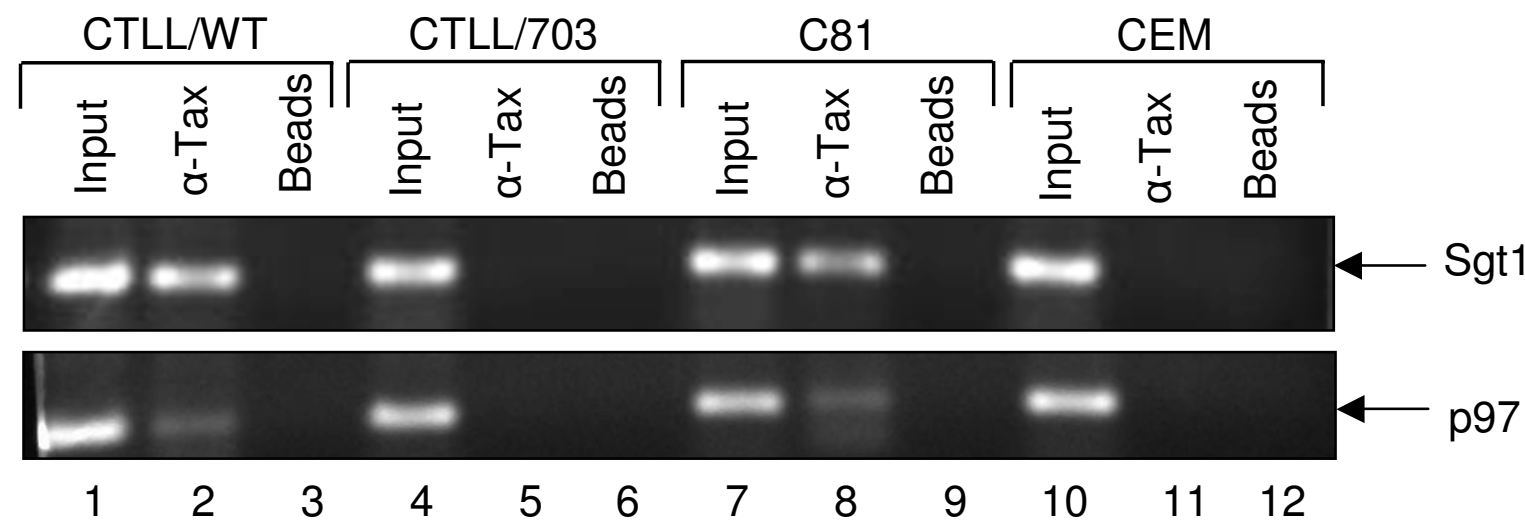

B)

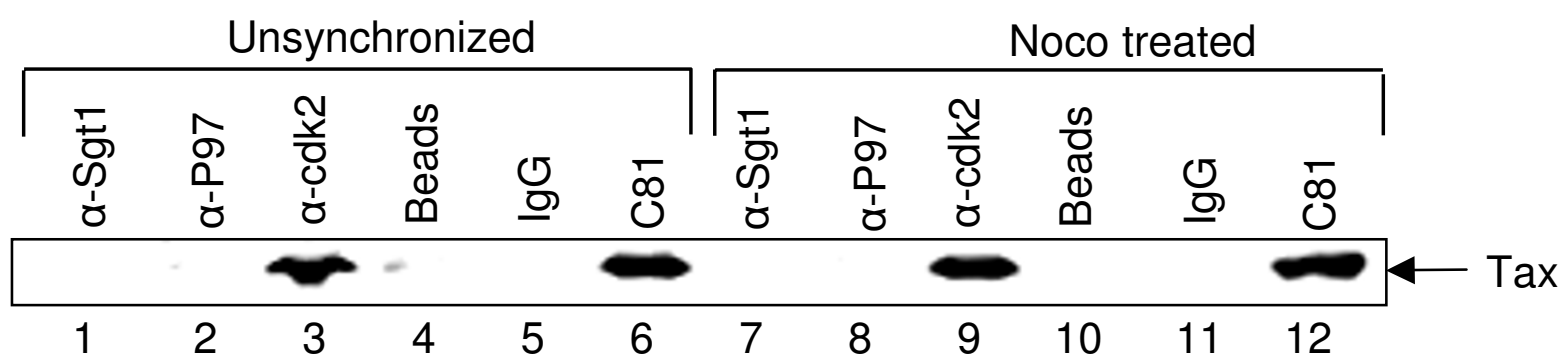

\section{Figure 6}

Effect of Tax on cellular promoters and its protein-protein interaction.A) Chromatin immunoprecipitation experiments were used to test whether Tax could occupy Sgt I or p97 promoters. CTLL/WT and CTLL/703 (7.5 $\times 10^{6}$ cells/ChIP), as well as C8I (Tax expressing, $5.5 \times 10^{6}$ cells/ChIP) and CEM (negative control with no Tax expression, $5.5 \times 10^{6}$ cells/ChIP) were cross-linked, and processed for ChIP assay. Lanes I, 4, 7 and 10 are "input" lanes where no immunoprecipitation was performed prior to PCR (positive control). Lanes 3, 6, 9 and 12 contained no antibody, and only beads, for the immunoprecipitation (negative control). Lanes 2, 5, 8 and II used a mixture of $500 \mathrm{ng}$ of each TAb anti-Tax monoclonal antibodies (I69, I70, I7I and I72; amount of each antibody judged by running $100 \mathrm{ng}$ of each purified antibody on 4-20\% SDS-PAGE and stained for Heavy and light chains) as the experimental sample. The high salt wash step after immunoprecipitation contained I000 mM (as opposed to $500 \mathrm{mM}$ ) salt. B) Two set of C8I cells were used for immunoprecipitation followed by western blot against Tax. First, unsynchronized $\mathrm{C} 8 \mathrm{I}$ cells $(2 \mathrm{mg}$ total cellular extract, Lanes I-6) where majority of cells were at the GI phase (7I\%), were used for immunoprecipitation with anti-Sgt I (I $\mu \mathrm{g})$, anti-p97 (I.2 $\mu \mathrm{g})$, anti-cdk2 (0.75 $\mu \mathrm{g})$ and IgG (I.2 $\mu \mathrm{g})$ followed by western blot with anti-Tax polyclonal antibody. We have previously used this method to define a list of Tax binding proteins using low and high salt wash conditions [69]. We also enriched C8I cells for G2/M population (67\%) by treating with low serum (I\%) and nocodazole (Noco, $50 \mathrm{ng} / \mathrm{ml}$ ) for $72 \mathrm{hrs}$ prior to the immunoprecipitation [ I5]. Lanes 4, 5, I0 and I I served as negative control for IP, and lanes 3 and 9 served as positive control for Tax binding protein under high salt conditions (cdk2). Lanes 6 and 12 were total cellular extract (Input, $50 \mu \mathrm{g}$ ) and lanes I, 2, 7 and 8 served as the experimental sample. The high salt wash after immunoprecipitation contained $1000 \mathrm{mM}$ salt.

required to functionally activate the Skp1 and Ctf13 subunits of the CBF3 kinetochore complex but is not itself a subunit of this complex [76]. Second, Sgt 1 may be present in substoichiometric quantities in SCF [76] and Cyr1 complexes regulating the $\mathrm{M}$ to $\mathrm{G} 1$ transition, and thirdly Sgt1, like SKP1, is required for both the G1/S and G2/M transitions during the cell cycle [79]. 


\section{Conclusion}

The Tax oncoprotein is considered the cause for mitotic aberrations in HTLV-I infected cells. In addition to binding checkpoint factors and interfering with the MSC function, we propose a mechanism by which Tax induces these aberrations through over-expression of factors associated with kinetochore assembly. Wild-type Tax-expressing cells displayed higher incidence of aneuploidy than the CREB transactivation deficient mutant. Through microarray and promoter analyses, we have identified 95 genes that were over-expressed in CTLL/WT cells which may be regulated through CREB activity. Furthermore, 11 of these genes are involved in G2/M phase regulation, in particular kinetochore regulation. We have confirmed the regulation of Sgt1 and p97/Vcp by CREB and Tax in vivo by performing ChIP analysis. The over-expression of these factors may contribute to the observed aneuploidy phenotype and disrupt proper targeting of their binding partners. The mitotic aberrations generated may be in the form of improper spindle attachment and disassembly process that results in chromosomal mis-segregation and hence aneuploidy.

\section{Methods \\ Cell culture}

Chronic T Lymphocytic Leukemia (CTLL) cells stably tranfected with either wild-type Tax or the M47 Tax mutant $\left({ }^{319} \mathrm{LL} \rightarrow \mathrm{AS}\right)$ have previously been described [31]. For the purpose of this study, they are designated as CTLL/WT (CTLL-2 cells transfected with wild type Tax) and CTLL/ 703 (CTLL-2 cells transfected with a CREB Tax mutant, M47). A comparison of Tax expression in WT and 703 cells has been published previously $[15,34]$. Cells were grown in RPMI-1640 with 10\% FBS, 1\% streptomycin, penicillin antibiotics, and 1\% L-glutamine, and at 5\% $\mathrm{CO} 2,37^{\circ} \mathrm{C}$.

\section{Metaphase chromosome spread}

CTLL/WT and CTLL/703 cells were incubated in $5 \mathrm{ml}$ of complete media for 48 hrs. Both cultures were treated with $50 \mu$ g colcemid for 45 mins. Next, samples were centrifuged at $160 \mathrm{~g}$ for $10 \mathrm{mins}$. Cells were incubated at room temperature in $0.075 \mathrm{M} \mathrm{KCl}$ for 30 minutes and then fixed in $1 \mathrm{ml}$ of methanol:glacial acetic acid (3:1). Cells were then centrifuged and washed again with the fixative solution for a total of three times. Finally, cells were resuspended in $250 \mu \mathrm{l}$ of fixative and dropped onto prechilled slides at $-20^{\circ} \mathrm{C}$ with a water vapor film formed on them just before dropping the cell suspension to induce better chromosome spread. Three to five drops of $70 \%$ glacial acetic acid was then added to remove cytoplasm. The slides were then allowed to dry overnight at room temperature. Slides were processed in Dulbecco's Phosphate Buffered Saline (D-PBS) for 1 minute, Giemsa stain working solution ( $2 \mathrm{ml}$ Giemsa stain diluted with 25 $\mathrm{ml}$ D-PBS) for 10 mins, and in distilled water for 30 secs. After being dried at room temperature, cover slips were mounted and allowed to dry. Slides were then imaged using the Olympus BX-60 microscope $(100 \mathrm{x}$, oil immersion) and Image-Pro Plus 5.1 software. Spreads with clearly visible and distinct chromosomes were then selected and counted.

\section{Cytoplasmic RNA isolation}

Cells were centrifuged at $4{ }^{\circ} \mathrm{C}, 3000 \mathrm{rpm}$ for $10 \mathrm{~min}$., quickly washed with D-PBS without $\mathrm{Ca} 2+/ \mathrm{Mg} 2+$, and centrifuged twice. Pelleted cells were immediately frozen at $80^{\circ} \mathrm{C}$ until all time points were collected. Cytoplasmic RNA was isolated utilizing the RNeasy Mini Kit (Qiagen, Valencia, CA) according to manufacturer's directions with the addition of $1 \mathrm{mM}$ dithiothreitol in Buffer RLN. Isolated RNA was quantified by UV spectrophotometric analysis and $3 \mu \mathrm{g}$ of RNA was visualized on a non-denaturing $1 \%$ agarose TAE gel for quality control.

\section{Expression profiling}

Six micrograms of cytoplasmic RNA from each sample was used to synthesize double-stranded cDNA using the Superscript Choice System kit and T7-(dT) 24 primer (100 $\mathrm{pmol} / \mu \mathrm{L}$ ) (Invitrogen). The cDNA was purified using phenol/chloroform extraction and ethanol precipitation. The cDNA was then used to perform in vitro transcription using the BioArray HighYield RNA Transcript Labeling Kit (T7) (Enzo, Farmingdale, NY). The biotin-labeled cRNA was purified using the RNeasy Mini Kit (Qiagen) and quantified by spectrophotometric analysis and analyzed on a $1 \%$ agarose TAE gel. The biotin-labeled cRNA was then randomly fragmented to $\sim \$ 35-200$ base pairs by metal-induced hydrolysis using a fragmentation buffer according to the Affymetrix Eukaryotic Target Hybridization protocol. Two Murine Genome U74A GeneChips (Affymetrix) were used per sample. This array contained 6,000 functionally characterized sequences from the Mouse UniGene database (Build 74) and 6,000 Expressed Sequence Tag (EST) clusters. The array was washed, primed, and stained on the Affymetrix Fluidics Station 400 following manufacturer's recommendations. cRNA was detected through a primary scan with phycoerythrinstreptavidin staining and then amplified with a second stain using biotin-labeled anti-streptavidin antibody and a subsequent phycoerythrin-streptavidin stain. The emitted fluorescence was scanned using the Hewlett-Packard G2500A Gene Array Scanner, and the intensities were extracted from the chips using Microarray Suite 4.0 (MAS4.0) software. All raw chip data was scaled in MAS4.0 to 800 to normalize signal intensities for interarray comparisons. 
Table 3: Primers used for PCR

\begin{tabular}{|c|c|c|c|c|c|}
\hline Accession \# & Gene ID & Forward & Reverse & Size(bp) & Correctly mapped \\
\hline D87898 & Arfl & ACCCTTGCTCGTTCTAGTGC & GGTTTCGCTCCCACAAGAT & 224 & Yes \\
\hline AF016583 & Chekl & CCACCACACTTGCTTTCСTT & GGAATCCAAATGCACAGCTT & 583 & Yes \\
\hline AF098508 & Dctn3 & TTTGGGTGTACGTCCTGACA & CAGCTCСTCCACTCGAGACT & 486 & Yes \\
\hline NM 009503 & p97(Vcp) & ATTGCCTTTGTCGATTGGTC & TCGGAAGGAAAGCTGCTCTA & 228 & Yes \\
\hline$\overline{\mathrm{BC} 046832}$ & Ppplcb & AGCAGGGAAGGAAGGTCATT & GGCGTTCTCACCTACGAGTC & 529 & Yes \\
\hline A]534939 & Smc2II & CTTACAGCCGTTTGCCTAGC & CCGTTTTGAACATGGAAAGC & 439 & Yes \\
\hline $\mathrm{BC} 009167$ & Sgtl & AGCCGACTTAGGAAGGAAGC & GTCTCGGAGCCCACTGTAAG & 325 & Yes \\
\hline AF077002 & Ywhah & AGGTCCCCGTAGGTATGTCC & CCCAGCCCTAACGGTCTT & 507 & Yes \\
\hline
\end{tabular}

\section{Data analysis}

Comparative analyses were performed by normalizing the fluorescence intensity of each probe using robust multiarray average (RMA), as previously described [91]. The mean of the signal intensities from duplicate experiments was calculated. To filter for differentially expressed genes, those genes that were absent in both experiments were excluded from further analysis. Those genes that were either up-or down-regulated in CTLL/WT cells by a magnitude of two-fold were compiled and functionally annotated utilizing the Database for Annotation, Visualization, and Integrated Discovery program (DAVID;[39]), as detailed in Figure 2.

Utilizing Genbank accession IDs, promoter sequences [2100 bp surrounding the predicted transcription start site (TSS)] for our annotated genes were retrieved from PromoSer $[47,48]$, a large-scale database containing the promoters of human, mouse, and rat genes. The following criteria were used for the retrieval: 1) promoter sequence encompassing 2000 bp upstream and 100 bp downstream of the TSS, 2) sequences were required to contain a quality score of at least 2 and support score of 2, i.e. TSS prediction is supported by one or more mRNAs, 3 ) in the case of alternative promoters only the one that is best supported and 5' was included, and 4) promoters that mapped to more than one loci or did not align well were excluded. At least one third of the promoter sequences retrieved were checked for proper alignment against the mouse genome using Blastn [92] and MapViewer [93] tools through NCBI. CREB (TGACGT/C), CREB/p300 (A/ GGGAGT), NFkB (GGGAA/CTTC/TCC), and SRF (CCCATATATGG) consensus sequences obtained through the TRANSFAC database [94] were searched within the promoters obtained. Factors that contained the CREB or CREB/p300 sequences within their promoters were further probed for genes that contribute directly to mitosis, cytokinesis, and microtubule organization.

\section{Chromatin immunoprecipitation}

Cells ( $5 \times 10^{6} /$ immunoprecipitation) were formaldehyde cross-linked ( $1 \%$ final volume, 15 mins. $\left.37^{\circ} \mathrm{C}\right)$. Nuclei, prepared by hypotonic lysis, were resuspended in lysis buffer (1\% SDS, 10 mM EDTA, 50 mM Tris-HCl, pH 8.1), sonicated to reduce DNA length to 200-1000 bp, and debris was removed by centrifugation. The chromatin solution was diluted 10 -fold by ChIP dilution buffer (0.01\% SDS, 1.1\% Triton X-100, 1.2 mM EDTA, $16.7 \mathrm{mM}$ Tris- $\mathrm{HCl}, \mathrm{pH} 8.1,167 \mathrm{mM} \mathrm{NaCl}$ ) and precleared on protein $\mathrm{A} / \mathrm{G}$ agarose beads pre-adsorbed with sonicated salmon sperm DNA $(10 \mathrm{mg} / \mathrm{ml})$ and bovine serum albu$\min ($ BSA $[10 \mathrm{mg} / \mathrm{ml}])$. The solution was then centrifuged and $1 \mathrm{ml}$ of the supernatant was stored separately at $4{ }^{\circ} \mathrm{C}$ to be used as input. Precleared chromatin was incubated with $10 \mu \mathrm{g}$ of antibody overnight at $4{ }^{\circ} \mathrm{C}$, followed by immunoprecipitation with $60 \mu \mathrm{l}$ of protein A/G-agarose beads per immunoprecipitation. Immune complexes were washed twice with Low Salt buffer (0.1\%SDS, 1\% Triton X-100, 2 mM EDTA, 20 mM Tris-HCl, pH 8.1), twice with High Salt buffer (0.1\%SDS, 1\% Triton X-100, 2 mM EDTA, 20 mM Tris-HCl, pH 8.1, $500 \mathrm{mM} \mathrm{NaCl}$ ), once with $\mathrm{LiCl}(0.25 \mathrm{M} \mathrm{LiCl}, 1 \% \mathrm{NP} 40,1 \%$ deoxycholate, 1 mM EDTA, $10 \mathrm{mM}$ Tris-HCl, pH 8.1) and once with $1 \mathrm{M}$ $\mathrm{TE}, \mathrm{pH}$ 8.0. Cross-linking was reversed by heating at $65^{\circ} \mathrm{C}$ overnight in the presence of $20 \mu \mathrm{l} 5 \mathrm{M} \mathrm{NaCl}$. DNA was recovered by digestion of proteins with $50 \mu \mathrm{g} / \mathrm{ml}$ proteinase $\mathrm{K}$ followed by phenol-chloroform extraction (twice) and ethanol precipitation. Recovered DNA was resuspended in TE, $\mathrm{pH}$ 8.0. 10\% of the recovered DNA was used for each PCR amplification (35 cycles). The primers used for PCR are as shown in Table 3.

\section{Competing interests}

The author(s) declare that they have no competing interests.

\section{Authors' contributions}

CdlF and MG drafted the manuscript. MG performed the metaphase chromosome spread. CdlF isolated RNA and contributed to the expression profiling experiment. AG and PS performed the expression profiling protocol on all samples. PC and TM helped with the gene expression analysis. CdlF and KS performed the promoter analysis. $\mathrm{MG}$ and $\mathrm{ZK}$ performed the ChIP experiments. MF pro- 
vided some of the reagents. CdIF, $\mathrm{AP}$, and FK contributed to the design, coordination, and validation of the study. All authors have read and approved the manuscript.

\section{Additional material}

\section{Additional File 1}

wtminus_grtthan_703minus_annotated.

Click here for file

[http://www.biomedcentral.com/content/supplementary/17424690-3-43-S1.xls]

\section{Additional File 2}

wtminus_less_703minus_annotated.

Click here for file

[http://www.biomedcentral.com/content/supplementary/17424690-3-43-S2.xls]

\section{Acknowledgements}

This work was supported by grants from the George Washington University REF funds to A. Vertes and F. Kashanchi, and NIH grants Al44357, Al43894 and 13969 to F.K.

\section{References}

I. Proietti FA, Carneiro-Proietti AB, Catalan-Soares BC, Murphy EL: Global epidemiology of HTLV-I infection and associated diseases. Oncogene 2005, 24:6058-6068.

2. Taylor GP, Matsuoka M: Natural history of adult T-cell leukemia/lymphoma and approaches to therapy. Oncogene 2005, 24:6047-6057.

3. Mahieux R, Gessain A: HTLV-I and associated adult T-cell leukemia/lymphoma. Rev Clin Exp Hematol 2003, 7:336-36I.

4. Murphy EL, Hanchard B, Figueroa JP, Gibbs WN, Lofters WS, Campbell $M$, Goedert J], Blattner WA: Modelling the risk of adult T-cell leukemia/lymphoma in persons infected with human T-lymphotropic virus type I. Int J Cancer 1989, 43:250-253.

5. Gatza ML, Watt JC, Marriott SJ: Cellular transformation by the HTLV-I Tax protein, a jack-of-all-trades. Oncogene 2003, 22:5|4|-5|49.

6. Liu B, Liang MH, Kuo YL, Liao W, Boros I, Kleinberger T, Blancato J, Giam CZ: Human T-lymphotropic virus type I oncoprotein tax promotes unscheduled degradation of $\mathrm{Pds} / \mathrm{p} / \mathrm{securin}$ and Clb2p/cyclin BI and causes chromosomal instability. Mol Cell Biol 2003, 23:5269-5281.

7. Shimoyama M: Diagnostic criteria and classification of clinical subtypes of adult T-cell leukaemia-lymphoma. A report from the Lymphoma Study Group (1984-87). Br J Haematol I991, 79:428-437.

8. Hisada M, Okayama A, Shioiri S, Spiegelman DL, Stuver SO, Mueller NE: Risk factors for adult T-cell leukemia among carriers of human T-lymphotropic virus type I. Blood I998, 92:3557-356I.

9. Fujimoto T, Hata T, Itoyama T, Nakamura H, Tsukasaki $K$, Yamada $Y$, Ikeda S, Sadamori N, Tomonaga M: High rate of chromosomal abnormalities in HTLV-I-infected T-cell colonies derived from prodromal phase of adult T-cell leukemia: a study of IL2-stimulated colony formation in methylcellulose. Cancer Genet Cytogenet 1999, 109:1-13.

10. Taguchi H, Miyoshi I: Three cases of pre-adult T-cell leukemia. Jpn J Clin Oncol 1983, I 3 Suppl 2:209-2।4.

II. Kinoshita K, Amagasaki T, Ikeda S, Suzuyama J, Toriya K, Nishino K, Tagawa M, Ichimaru M, Kamihira S, Yamada Y, et al.: Preleukemic state of adult $T$ cell leukemia: abnormal $T$ lymphocytosis induced by human adult $\mathbf{T}$ cell leukemia-lymphoma virus. Blood 1985, 66: 120-127.

12. Sacher RA, Luban NL, Ameti DI, Friend S, Schreiber GB, Murphy EL: Low prevalence of flower cells in U.S.A. blood donors infected with human T-lymphotrophic virus types I and II. $\mathrm{Br}$ J Haematol 1999, I 05:758-763.

13. Kops GJ, Weaver BA, Cleveland DW: On the road to cancer: aneuploidy and the mitotic checkpoint. Nat Rev Cancer 2005, 5:773-785.

14. Lazaris AC, Kavantzas NG, Zorzos HS, Tsavaris NV, Davaris PS: Markers of drug resistance in relapsing colon cancer. J Cancer Res Clin Oncol 2002, I 28: I |4-I I8.

15. Santiago F, Clark E, Chong S, Molina C, Mozafari F, Mahieux R, Fujii $M$, Azimi N, Kashanchi F: Transcriptional up-regulation of the cyclin D2 gene and acquisition of new cyclin-dependent kinase partners in human T-cell leukemia virus type Iinfected cells. J Virol 1999, 73:9917-9927.

16. Lemoine FJ, Marriott SJ: Accelerated G(I) phase progression induced by the human $T$ cell leukemia virus type I (HTLV-I) Tax oncoprotein. J Biol Chem 200I, 276:3185I-31857.

17. Haoudi A, Semmes OJ: The HTLV-I tax oncoprotein attenuates DNA damage induced GI arrest and enhances apoptosis in p53 null cells. Virology 2003, 305:229-239.

18. Grassmann R, Aboud M, Jeang KT: Molecular mechanisms of cellular transformation by HTLV-I Tax. Oncogene 2005, 24:5976-5985.

19. Zhao RY, Elder RT: Viral infections and cell cycle G2/M regulation. Cell Res 2005, I5:|43-149.

20. Azran I, Schavinsky-Khrapunsky Y, Aboud M: Role of Tax protein in human $\mathbf{T}$-cell leukemia virus type-I leukemogenicity. Retrovirology 2004, I :20.

21. Jeang KT, Giam CZ, Majone F, Aboud M: Life, Death and Tax: role of HTLV-I oncoprotein in genetic instability and cellular transformation. J Biol Chem 2004.

22. Jin DY, Spencer F, Jeang KT: Human T cell leukemia virus type I oncoprotein Tax targets the human mitotic checkpoint protein MADI. Cell I998, 93:8I-9I.

23. Kasai T, Iwanaga $Y$, lha $H$, Jeang KT: Prevalent loss of mitotic spindle checkpoint in adult $\mathrm{T}$-cell leukemia confers resistance to microtubule inhibitors. J Biol Chem 2002, 277:5187-5I 93.

24. Haoudi A, Daniels RC, Wong E, Kupfer G, Semmes OJ: Human Tcell leukemia virus-I tax oncoprotein functionally targets a subnuclear complex involved in cellular DNA damageresponse. J Biol Chem 2003, 278:37736-37744.

25. Park HU, Jeong JH, Chung JH, Brady JN: Human T-cell leukemia virus type I Tax interacts with Chk I and attenuates DNAdamage induced G2 arrest mediated by Chk I. Oncogene 2004, 23:4966-4974.

26. Liu B, Hong S, Tang Z, Yu H, Giam CZ: HTLV-I Tax directly binds the Cdc20-associated anaphase-promoting complex and activates it ahead of schedule. Proc Natl Acad Sci U S A 2005, 1 02:63-68.

27. Hagting A, Den Elzen N, Vodermaier HC, Waizenegger IC, Peters JM, Pines J: Human securin proteolysis is controlled by the spindle checkpoint and reveals when the APC/C switches from activation by Cdc20 to Cdh I. J Cell Biol 2002, I 57:I I 25-I I 37.

28. Park HU, Jeong SJ, Jeong JH, Chung JH, Brady JN: Human T-cell leukemia virus type I Tax attenuates gamma-irradiationinduced apoptosis through physical interaction with Chk2. Oncogene 2006, 25:438-447.

29. Majone F, Semmes OJ, Jeang KT: Induction of micronuclei by HTLV-I Tax: a cellular assay for function. Virology 1993, 193:456-459.

30. Majone F, Luisetto R, Zamboni D, Iwanaga Y, Jeang KT: Ku protein as a potential human T-cell leukemia virus type I (HTLV-I) Tax target in clastogenic chromosomal instability of mammalian cells. Retrovirology 2005, 2:45.

31. Peloponese JMJ, Iha H, Yedavalli VR, Miyazato A, Li Y, Haller K, Benkirane $M$, Jeang KT: Ubiquitination of human $\mathbf{T}$-cell leukemia virus type I tax modulates its activity. J Virol 2004, 78: I |686-I I695.

32. Yoshida M, Inoue J, Fujisawa J, Seiki M: Molecular mechanisms of regulation of HTLV-I gene expression and its association with leukemogenesis. Genome 1989, 3 I:662-667.

33. Wu K, Bottazzi ME, de la Fuente C, Deng L, Gitlin SD, Maddukuri A, Dadgar S, Li H, Vertes A, Pumfery A, Kashanchi F: Protein profile of tax-associated complexes. J Biol Chem 2004, 279:495-508.

34. Chen L, Ma S, Li B, Fink T, Zachar V, Takahashi M, Cuttichia J, Tsui LC, Ebbesen P, Liu X: Transcriptional activation of immediate- 
early gene ETRIOI by human T-cell leukaemia virus type I Tax. J Gen Virol 2003, 84:3203-32I4.

35. Alexandre C, Charnay P, Verrier B: Transactivation of Krox-20 and Krox-24 promoters by the HTLV-I Tax protein through common regulatory elements. Oncogene 199|, 6: I85I-I857.

36. Marriott SJ, Lemoine FJ, Jeang KT: Damaged DNA and miscounted chromosomes: human $\mathrm{T}$ cell leukemia virus type I tax oncoprotein and genetic lesions in transformed cells. J Biomed Sci 2002, 9:292-298.

37. Jallepalli PV, Waizenegger IC, Bunz F, Langer S, Speicher MR, Peters JM, Kinzler KW, Vogelstein B, Lengauer C: Securin is required for chromosomal stability in human cells. Cell 200I, 105:445-457.

38. Wang Z, Yu R, Melmed S: Mice lacking pituitary tumor transforming gene show testicular and splenic hypoplasia, thymic hyperplasia, thrombocytopenia, aberrant cell cycle progression, and premature centromere division. Mol Endocrinol 200I, I 5:1870-1879.

39. Neuveut C, Low KG, Maldarelli F, Schmitt I, Majone F, Grassmann R, Jeang KT: Human T-cell leukemia virus type I Tax and cell cycle progression: role of cyclin D-cdk and pI I ORb. Mol Cell Biol 1998, I 8:3620-3632.

40. Iwanaga $Y$, Tsukahara T, Ohashi T, Tanaka $Y$, Arai M, Nakamura M, Ohtani K, Koya Y, Kannagi M, Yamamoto N, Fujii M: Human T-cell leukemia virus type I tax protein abrogates interleukin-2 dependence in a mouse T-cell line. J Virol 1999, 73:127|-| 277.

41. Waldmann TA: The promiscuous IL-2/IL-I5 receptor: a target for immunotherapy of HTLV-I-associated disorders. J Acquir Immune Defic Syndr Hum Retrovirol 1996, I3 Suppl I:SI79-85.

42. Iwai K, Mori N, Oie M, Yamamoto N, Fujii M: Human T-cell leukemia virus type I tax protein activates transcription through AP-I site by inducing DNA binding activity in T cells. Virology 200I, 279:38-46.

43. de la Fuente C, Wang L, Wang D, Deng L, Wu K, Li H, Stein LD, Denny T, Coffman F, Kehn K, Baylor S, Maddukuri A, Pumfery A Kashanchi F: Paradoxical effects of a stress signal on pro- and anti-apoptotic machinery in HTLV-I Tax expressing cells. Mol Cell Biochem 2003, 245:99-II3.

44. Distelhorst CW, Benutto BM, Bergamini RA: Centrifugal elutriation of human lymphoid cells: synchronization and separation of aneuploid cells into diploid and tetraploid populations. Cell Immunol 1983, 79:68-80.

45. Davies R, Cain K, Edwards RE, Snowden RT, Legg RF, Neal GE: The preparation of highly enriched fractions of binucleated rat hepatocytes by centrifugal elutriation and flow cytometry. Anal Biochem 1990, 190:266-270.

46. Mann MB, Hodges CA, Barnes E, Vogel H, Hassold TJ, Luo G: Defective sister-chromatid cohesion, aneuploidy and cancer predisposition in a mouse model of type II Rothmund-Thomson syndrome. Hum Mol Genet 2005, 14:813-825.

47. Guenet JL: The mouse genome. Genome Res 2005, I5: I 729-1740.

48. Dennis G], Sherman BT, Hosack DA, Yang J, Gao W, Lane HC, Lempicki RA: DAVID: Database for Annotation, Visualization, and Integrated Discovery. Genome Biol 2003, 4:P3.

49. de la Fuente C, Santiago F, Chong SY, Deng L, Mayhood T, Fu P, Stein D, Denny T, Coffman F, Azimi N, Mahieux R, Kashanchi F: Overexpression of p2I(wafl) in human T-cell lymphotropic virus type I-infected cells and its association with cyclin A/cdk2. J Virol 2000, 74:7270-7283.

50. Fujii M, Niki T, Mori T, Matsuda T, Matsui M, Nomura N, Seiki M: HTLV-I Tax induces expression of various immediate early serum responsive genes. Oncogene 1991, 6:1023-1029.

5I. Sekkai D, Gruel G, Herry M, Moucadel V, Constantinescu SN, Albagli O, Tronik-Le Roux D, Vainchenker W, Bennaceur-Griscelli A: Microarray analysis of LIF/Stat3 transcriptional targets in embryonic stem cells. Stem Cells 2005, 23:1634-1642.

52. Vandepoele K, Vlieghe K, Florquin K, Hennig L, Beemster GT, Gruissem W, Van de Peer Y, Inze D, De Veylder L: Genome-wide identification of potential plant E2F target genes. Plant Physiol 2005, 139:316-328.

53. Worden B, Yang XP, Lee TL, Bagain L, Yeh NT, Cohen JG, Van Waes C, Chen Z: Hepatocyte growth factor/scatter factor differentially regulates expression of proangiogenic factors through Egr- $I$ in head and neck squamous cell carcinoma. Cancer Res 2005, 65:707I-7080.
54. Allocco DJ, Kohane IS, Butte AJ: Quantifying the relationship between co-expression, co-regulation and gene function. BMC Bioinformatics 2004, 5:18.

55. Argyropoulos C, Nikiforidis GC, Theodoropoulou M, Adamopoulos P, Boubali S, Georgakopoulos TN, Paliogianni F, Papavassiliou AG, Mouzaki A: Mining microarray data to identify transcription factors expressed in naive resting but not activated $\mathrm{T}$ lymphocytes. Genes Immun 2004, 5:16-25.

56. Halees AS, Leyfer D, Weng Z: PromoSer: A large-scale mammalian promoter and transcription start site identification service. Nucleic Acids Res 2003, 3 1:3554-3559.

57. Halees AS, Weng Z: PromoSer: improvements to the algorithm, visualization and accessibility. Nucleic Acids Res 2004, 32:W|9|-4.

58. Quinn PG, Wong TW, Magnuson MA, Shabb JB, Granner DK: Identification of basal and cyclic AMP regulatory elements in the promoter of the phosphoenolpyruvate carboxykinase gene. Mol Cell Biol I 988, 8:3467-3475.

59. Jameson JL, Jaffe RC, Deutsch PJ, Albanese C, Habener JF: The gonadotropin alpha-gene contains multiple protein binding domains that interact to modulate basal and CAMP-responsive transcription. J Biol Chem 1988, 263:9879-9886.

60. Rikitake $Y$, Moran E: DNA-binding properties of the EIA-associated 300-kilodalton protein. Mol Cell Biol 1992, I 2:2826-2836.

61. Chen H, Hung MC: Involvement of co-activator p300 in the transcriptional regulation of the HER-2/neu gene. J Biol Chem 1997, 272:6101-6104.

62. Kashanchi F, Brady JN: Transcriptional and post-transcriptional gene regulation of HTLV-I. Oncogene 2005, 24:5938-595I.

63. Westermann S, Cheeseman IM, Anderson S, Yates JR, Drubin DG, Barnes G: Architecture of the budding yeast kinetochore reveals a conserved molecular core. J Cell Biol 2003, 163:215-222

64. De Wulf P, McAinsh AD, Sorger PK: Hierarchical assembly of the budding yeast kinetochore from multiple subcomplexes. Genes Dev 2003, 17:2902-2921.

65. Rieder CL, Salmon ED: The vertebrate cell kinetochore and its roles during mitosis. Trends Cell Biol 1998, 8:310-318.

66. Zhou J, Yao J, Joshi HC: Attachment and tension in the spindle assembly checkpoint. J Cell Sci 2002, I I 5:3547-3555.

67. Echeverri CJ, Paschal BM, Vaughan KT, Vallee RB: Molecular characterization of the 50-kD subunit of dynactin reveals function for the complex in chromosome alignment and spindle organization during mitosis. J Cell Biol 1996, 132:617-633.

68. Tomonaga T, Matsushita K, Ishibashi M, Nezu M, Shimada H, Ochiai $T$, Yoda $K$, Nomura F: Centromere protein $\mathbf{H}$ is up-regulated in primary human colorectal cancer and its overexpression induces aneuploidy. Cancer Res 2005, 65:4683-4689.

69. Tomonaga T, Matsushita K, Yamaguchi S, Oohashi T, Shimada H, Ochiai T, Yoda K, Nomura F: Overexpression and mistargeting of centromere protein-A in human primary colorectal cancer. Cancer Res 2003, 63:35II-3516.

70. Kuo MH, Allis $C D$ : In vivo cross-linking and immunoprecipitation for studying dynamic Protein:DNA associations in a chromatin environment. Methods 1999, 19:425-433.

7I. Spiller MP, Kambadur R, Jeanplong F, Thomas M, Martyn JK, Bass IJ, Sharma $M$ : The myostatin gene is a downstream target gene of basic helix-loop-helix transcription factor MyoD. Mol Cell Biol 2002, 22:7066-7082.

72. Holmes MC, Tjian R: Promoter-selective properties of the TBP-related factor TRFI. Science 2000, 288:867-870.

73. de la Fuente C, Deng L, Santiago F, Arce L, Wang L, Kashanchi F: Gene expression array of HTLV type I-infected T cells: Upregulation of transcription factors and cell cycle genes. AIDS Res Hum Retroviruses 2000, 16:1695-1700.

74. Ashburner BP, Westerheide SD, Baldwin ASJ: The p65 (RelA) subunit of NF-kappaB interacts with the histone deacetylase (HDAC) corepressors HDACI and HDAC2 to negatively regulate gene expression. Mol Cell Biol 200I, 21 :7065-7077.

75. Steensgaard P, Garre M, Muradore I, Transidico P, Nigg EA, Kitagawa $\mathrm{K}$, Earnshaw WC, Faretta M, Musacchio A: Sgt I is required for human kinetochore assembly. EMBO Rep 2004, 5:626-63I.

76. Andrisani OM: CREB-mediated transcriptional control. Crit Rev Eukaryot Gene Expr 1999, 9:19-32.

77. Niikura $Y$, Kitagawa $K$ : Identification of a novel splice variant: human SGTIB (SUGTIB). DNA Seq 2003, I4:436-44I 
78. Yamamoto S, Tomita Y, Hoshida Y, Nagano H, Dono K, Umeshita K, Sakon M, Ishikawa O, Ohigashi H, Nakamori S, Monden M, Aozasa K: Increased expression of valosin-containing protein (p97) is associated with lymph node metastasis and prognosis of pancreatic ductal adenocarcinoma. Ann Surg Oncol 2004, I I:165-172.

79. Hetzer M, Meyer HH, Walther TC, Bilbao-Cortes D, Warren G, Mattaj IW: Distinct AAA-ATPase p97 complexes function in discrete steps of nuclear assembly. Nat Cell Biol 200 I, 3: I086- I09I.

80. Cao K, Zheng Y: The Cdc48/p97-UfdI-Npl4 complex: its potential role in coordinating cellular morphogenesis during the M-G I transition. Cell Cycle 2004, 3:422-424.

8I. Fu X, $\mathrm{Ng} C$, Feng $D$, Liang $C$ : Cdc48p is required for the cell cycle commitment point at Start via degradation of the G I-CDK inhibitor Far I p. I Cell Biol 2003, I 63:21-26.

82. Chevalier MS, Johnson DC: Human cytomegalovirus US3 chimeras containing US2 cytosolic residues acquire major histocompatibility class I and II protein degradation properties. J Virol 2003, 77:473 I-4738.

83. Rabinovich E, Kerem A, Frohlich KU, Diamant N, Bar-Nun S: AAAATPase $\mathrm{p} 97 / \mathrm{Cdc48p}$, a cytosolic chaperone required for endoplasmic reticulum-associated protein degradation. Mol Cell Biol 2002, 22:626-634.

84. Kitagawa K, Skowyra D, Elledge SJ, Harper JW, Hieter P: SGTI encodes an essential component of the yeast kinetochore assembly pathway and a novel subunit of the SCF ubiquitin ligase complex. Mol Cell 1999, 4:21-33.

85. Rodrigo-Brenni MC, Thomas S, Bouck DC, Kaplan KB: Sgt Ip and Skplp modulate the assembly and turnover of CBF3 complexes required for proper kinetochore function. Mol Biol Cell 2004, I 5:3366-3378.

86. Lingelbach LB, Kaplan KB: The interaction between Sgt Ip and Skp Ip is regulated by HSP90 chaperones and is required for proper CBF3 assembly. Mol Cell Biol 2004, 24:8938-8950.

87. Yamamoto T, Mori Y, Ishibashi T, Uchiyama Y, Sakaguchi N, Furukawa T, Hashimoto J, Kimura S, Sakaguchi K: Characterization of Rad6 from a higher plant, rice (Oryza sativa L.) and its interaction with Sgt I, a subunit of the SCF ubiquitin ligase complex. Biochem Biophys Res Commun 2004, 3 I 4:434-439.

88. Thevelein JM, de Winde $\mathrm{JH}$ : Novel sensing mechanisms and targets for the CAMP-protein kinase A pathway in the yeast Saccharomyces cerevisiae. Mol Microbiol 1999, 33:904-918.

89. Field J, Xu HP, Michaeli T, Ballester R, Sass P, Wigler M, Colicelli J: Mutations of the adenylyl cyclase gene that block RAS function in Saccharomyces cerevisiae. Science 1990, 247:464-467.

90. Shima F, Okada T, Kido M, Sen H, Tanaka Y, Tamada M, Hu CD, Yamawaki-Kataoka Y, Kariya K, Kataoka T: Association of yeast adenylyl cyclase with cyclase-associated protein CAP forms a second Ras-binding site which mediates its Ras-dependent activation. Mol Cell Biol 2000, 20:26-33.

91. Suzuki N, Choe HR, Nishida Y, Yamawaki-Kataoka Y, Ohnishi S, Tamaoki T, Kataoka T: Leucine-rich repeats and carboxyl terminus are required for interaction of yeast adenylate cyclase with RAS proteins. Proc Natl Acad Sci U S A 1990, 87:87I I-87I 5.

92. Beebe SJ: The cAMP-dependent protein kinases and CAMP signal transduction. Semin Cancer Biol I 994, 5:285-294.

93. Tasken K, Skalhegg BS, Tasken KA, Solberg R, Knutsen HK, Levy FO, Sandberg M, Orstavik S, Larsen T, Johansen AK, Vang T, Schrader HP, Reinton NT, Torgersen KM, Hansson V, Jahnsen T: Structure, function, and regulation of human cAMP-dependent protein kinases. Adv Second Messenger Phosphoprotein Res 1997, 3 I: | 9|-204.

94. Baroni MD, Monti P, Alberghina L: Repression of growth-regulated GI cyclin expression by cyclic AMP in budding yeast. Nature 1994, 37 I:339-342.

95. Hall DD, Markwardt DD, Parviz F, Heideman W: Regulation of the CIn3-Cdc28 kinase by CAMP in Saccharomyces cerevisiae. Embo J 1998, 17:4370-4378.

96. Tokiwa G, Tyers M, Volpe T, Futcher B: Inhibition of GI cyclin activity by the Ras/cAMP pathway in yeast. Nature 1994 37 I:342-345.

97. Irniger S, Baumer $M$, Braus $\mathrm{GH}$ : Glucose and ras activity influence the ubiquitin ligases APC/C and SCF in Saccharomyces cerevisiae. Genetics 2000, I 54:1509-1521.

98. Young JC, Moarefi I, Hartl FU: Hsp90: a specialized but essential protein-folding tool. I Cell Biol 200I, 154:267-273.
99. Bolstad BM, Irizarry RA, Astrand M, Speed TP: A comparison of normalization methods for high density oligonucleotide array data based on variance and bias. Bioinformatics 2003, 19:185-193.

100. Basic Local Alignment Search Tool (nucleotide-nucleotide BLAST- BLASTn) [http://www.ncbi.nlm.nih.gov/BLAST/].

I0I. NCBI Map Viewer [http://www.ncbi.nlm.nih.gov/mapview/].

102. TRANSFAC database [http://www.gene-regulation.com/ pub/databases.html\#transfac].

103. Altan-Bonnet N, Phair RD, Polishchuk RS, Weigert R, LippincottSchwartz J: A role for Arfl in mitotic Golgi disassembly, chromosome segregation, and cytokinesis. Proc Natl Acad Sci U S A 2003, 100:13314-13319.

104. Gant TM, Wilson KL: ARF is not required for nuclear vesicle fusion or mitotic membrane disassembly in vitro: evidence for a non-ARF GTPase in fusion. Eur J Cell Biol 1997, 74:10-19.

105. Boman AL, Taylor TC, Melancon P, Wilson KL: A role for ADP. ribosylation factor in nuclear vesicle dynamics. Nature 1992 , 358:5|2-5|4.

106. Middendorp S, Kuntziger T, Abraham Y, Holmes S, Bordes N, Paintrand $M$, Paoletti $A$, Bornens $M$ : A role for centrin 3 in centrosome reproduction. / Cell Biol 2000, |48:405-4I6.

107. Middendorp S, Paoletti A, Schiebel E, Bornens M: Identification of a new mammalian centrin gene, more closely related to Saccharomyces cerevisiae CDC3I gene. Proc Natl Acad Sci U S A 1997, 94:9|4|-9|46.

108. Antoniacci LM, Kenna MA, Uetz P, Fields S, Skibbens RV: The spindle pole body assembly component mps3p/nep $98 \mathrm{p}$ functions in sister chromatid cohesion. J Biol Chem 2004, 279:49542-49550.

109. Paoletti A, Bordes N, Haddad R, Schwartz CL, Chang F, Bornens M: Fission yeast cdc3 Ip is a component of the half-bridge and controls SPB duplication. Mol Biol Cell 2003, I 4:2793-2808.

I I0. Errabolu R, Sanders MA, Salisbury JL: Cloning of a cDNA encoding human centrin, an EF-hand protein of centrosomes and mitotic spindle poles. / Cell Sci 1994, I 07 ( Pt I):9-16

I I I. Baum P, Furlong C, Byers B: Yeast gene required for spindle pole body duplication: homology of its product with $\mathrm{Ca2+-binding}$ proteins. Proc Natl Acad Sci U S A 1986, 83:55 I 2-55। 6.

I 12. Syljuasen RG, Sorensen CS, Hansen LT, Fugger K, Lundin C, Johansson F, Helleday T, Sehested M, Lukas J, Bartek J: Inhibition of human Chk l causes increased initiation of DNA replication, phosphorylation of ATR targets, and DNA breakage. Mol Cell Biol 2005, 25:3553-3562.

I 13. Sorensen CS, Hansen LT, Dziegielewski J, Syljuasen RG, Lundin C, Bartek J, Helleday T: The cell-cycle checkpoint kinase Chk I is required for mammalian homologous recombination repair. Nat Cell Biol 2005, 7:195-20I.

I 14. Zachos G, Rainey MD, Gillespie DA: Chk I-dependent S-M checkpoint delay in vertebrate cells is linked to maintenance of viable replication structures. Mol Cell Biol 2005, 25:563-574.

I I5. Pfister KK, Benashski SE, Dillman JF, Patel-King RS, King SM: Identification and molecular characterization of the p24 dynactin light chain. Cell Motil Cytoskeleton 1998, 41:I54-167.

116. Merdes A, Ramyar K, Vechio JD, Cleveland DW: A complex of NuMA and cytoplasmic dynein is essential for mitotic spindle assembly. Cell 1996, 87:447-458.

II7. Starr DA, Williams BC, Hays TS, Goldberg ML: ZWIO helps recruit dynactin and dynein to the kinetochore. J Cell Biol 1998 , 142:763-774.

I I8. Vallee RB, Vaughan KT, Echeverri C]: Targeting of cytoplasmic dynein to membranous organelles and kinetochores via dynactin. Cold Spring Harb Symp Quant Biol 1995, 60:803-8I I.

I19. Cao K, Nakajima R, Meyer HH, Zheng Y: The AAA-ATPase Cdc48/p97 regulates spindle disassembly at the end of mitosis. Cell 2003, II 5:355-367.

120. Cheeseman IM, Desai A: Cell division: AAAtacking the mitotic spindle. Curr Biol 2004, I4:R70-2.

12I. Uchiyama K, Jokitalo E, Lindman M, Jackman M, Kano F, Murata M, Zhang $X$, Kondo $H$ : The localization and phosphorylation of p47 are important for Golgi disassembly-assembly during the cell cycle. I Cell Biol 2003, 16 1:1067-1079.

122. Ceulemans H, Bollen M: Functional diversity of protein phosphatase-I, a cellular economizer and reset button. Physiol Rev 2004, 84: 1-39. 
123. Itoh H, Wortman MJ, Kanovsky M, Uson RR, Gordon RE, Alfano N, Johnson EM: Alterations in Pur(alpha) levels and intracellular localization in the CV-I cell cycle. Cell Growth Differ 1998, 9:65I-665.

124. Stacey DW, Hitomi M, Kanovsky M, Gan L, Johnson EM: Cell cycle arrest and morphological alterations following microinjection of NIH3T3 cells with Pur alpha. Oncogene 1999, | 8:4254-4261.

125. Hirano T: SMC-mediated chromosome mechanics: a conserved scheme from bacteria to vertebrates? Genes Dev 1999, 13:11-19.

126. Schmiesing JA, Ball ARJ, Gregson HC, Alderton JM, Zhou S, Yokomori $\mathrm{K}$ : Identification of two distinct human SMC protein complexes involved in mitotic chromosome dynamics. Proc Natl Acad Sci U S A 1998, 95: 12906-I29|I.

127. Schmiesing JA, Gregson HC, Zhou S, Yokomori K: A human condensin complex containing hCAP-C-hCAP-E and CNAPI, a homolog of Xenopus XCAP-D2, colocalizes with phosphorylated histone $\mathrm{H} 3$ during the early stage of mitotic chromosome condensation. Mol Cell Biol 2000, 20:6996-7006.

128. Przewloka MR, Pardington PE, Yannone SM, Chen DJ, Cary RB: In vitro and in vivo interactions of DNA ligase IV with a subunit of the condensin complex. Mol Biol Cell 2003, 14:685-697.

129. Mils V, Baldin V, Goubin F, Pinta I, Papin C, Waye M, Eychene A, Ducommun B: Specific interaction between 14-3-3 isoforms and the human CDC25B phosphatase. Oncogene 2000, 19:1257-1265

130. Uchida S, Kuma A, Ohtsubo M, Shimura M, Hirata M, Nakagama $H$, Matsunaga $T$, Ishizaka $Y$, Yamashita K: Binding of 14-3-3beta but not 14-3-3sigma controls the cytoplasmic localization of CDC25B: binding site preferences of 14-3-3 subtypes and the subcellular localization of CDC25B. J Cell Sci 2004, I I 7:30II-3020.

13I. Wang H, Hu X, Ding X, Dou Z, Yang Z, Shaw AW, Teng M, Cleveland DW, Goldberg ML, Niu L, Yao X: Human Zwint-I specifies localization of Zeste White 10 to kinetochores and is essential for mitotic checkpoint signaling. I Biol Chem 2004, 279:54590-54598.

132. Kops GJ, Kim Y, Weaver BA, Mao Y, McLeod I, Yates JR, Tagaya M, Cleveland DW: ZW 10 links mitotic checkpoint signaling to the structural kinetochore. J Cell Biol 2005, 169:49-60.

\section{Publish with Bio Med Central and every scientist can read your work free of charge}

"BioMed Central will be the most significant development for disseminating the results of biomedical research in our lifetime. "

Sir Paul Nurse, Cancer Research UK

Your research papers will be:

- available free of charge to the entire biomedical community

- peer reviewed and published immediately upon acceptance

- cited in PubMed and archived on PubMed Central

- yours - you keep the copyright

Submit your manuscript here:

http://www.biomedcentral.com/info/publishing_adv.asp
BioMedcentral 